\title{
STRATEGIJSKI MENADŽMENT U VOJNOORGANIZACIJONIM SISTEMIMA
}

\author{
Nenad V. Kovačević \\ Univerzitet odbrane u Beogradu, Vojna akademija, Kadetska brigada \\ Stjepan Domjančić \\ Hrvatsko vojno učilište „dr Franjo Tuđman“, Dekanat, Zagreb \\ Mitar P. Kovač ${ }^{* *}$ \\ Univerzitet Edukons, Fakultet za projektni i inovacioni menadžment, Beograd
}

\begin{abstract}
Strategijski menadžment svoju evoluciju proživljava poslednjih 50 tak godina. U tom vremenskom periodu strategijski menadžment je prešao put od tehnike dugoročnog planiranja do veoma značajne specijalizovane menadžment discipline. Počeci strategijskog menadžmenta vezuju se za početak šeste decenije 20 . veka i njegov razvoj teče paralelno sa razvojem različitih pristupa u definisanju strategije. Autori objašnjavaju specifičnosti prelaska strategije iz ,čisto“ vojnog u komercijalni ambijent. U radu su date osnovne teoretske odredbe vezane za istorijsku genezu menadžmenta, sa posebnim osvrtom na strategijski menadžment, takođe objašnjeni su i osnovni sadržaji i funkcije strategijskog menadžmenta, kao i specifičnosti njegove primene u jednom vojnoorganizacionom sistemu, konkretno sistemu odbrane Republike Srbije.
\end{abstract}

Ključne reči: strategija, strategijski menadžment, vojnoorganizacioni sistemi

Dadi osvajanja novih prostora i zaštite sopstvenih, postojećih staništa, čovek je počeo da se organizuje u zajednice, a sa pojavom prvih uređenih zajednica počelo je i vojno organizovanje sa jedne, ali i podela rada unutar zajednice sa druge strane. Prve uređene zajednice smatraju se pretečama menadžmenta, procesa koji će vremenom evoluirati prevashodno zahvaljujući opštem progresu ljudskog roda. Međutim, menadžment se kao delatnost pojavljuje tek u 19. veku, a kao naučna disciplina u 20. veku.

Menadžment je multidisciplinaran fenomen i problem i može se analizirati sa više različitih aspekata, odnosno naučnih disciplina - ekonomije, sociologije, teorije organizacije i drugih. Naime, ako menadžment posmatramo sa aspekta ekonomije, odnosno kao proizvodni faktor trebamo reći da je menadžment ekonomski resurs, jer on direktno utiče na povećanje ili smanjenje produktivnosti i profitabilnosti organizacije, a šire gledano može zameniti rad i kapital.

\footnotetext{
* Dr sc Stjepan Domjančić, brigadir, nalazi se na dužnosti prodekana za međunarodnu saradnju.

** Prof. dr. Mitar P. Kovač je general-major u penziji.
} 
Menadžment sa sociološkog stanovišta predstavlja klasni i statusni simbol, odnosno sa pojavom menadžera kao zanimanja vremenom se stvorila nova visoko obrazovana i intelektualna klasa, odnosno nova elita. Preduslov za ulazak u ovu elitu su znanje, sposobnosti i obrazovanje. Ako menadžment posmatramo sa aspekta teorije organizacije, onda možemo reći da on predstavlja svojevrsni sistem vlasti, jer se njime omogućuje postojanje ovlašćene grupe ljudi u realizaciji određenih poslova. Ovo stanovište je vremenom imalo različite pristupe, počev od autoritarnog koncepta, preko humanističkih koncepata do parcipativnog pristupa. Moderni menadžment predstavlja sintezu svih navedenih pristupa, zato se on i smatra hibridnim oblikom izvornog menadžmenta.

Strategijski ili strateški menadžment je jedna od modernih specijalizovanih menadžment disciplina, koja je nastala sredinom 20. veka, i svoju evoluciju doživljava kao jedna od indirektnih posledica globalizacije i ubrzanog opšteg naučno-tehnološko-informacionog napretka čovečanstva. Strategijsko upravljanje i strategijski menadžment su sinonimi, ali se u praksi češće koristi termin strategijskog menadžmenta, prevashodno zbog lakšeg terminološkog prepoznavanja i suštinskog shvatanja. Esencija strategijskog menadžmenta je strategijsko planiranje, koje predstavlja periodičnu aktivnost koja se preduzima radi suočavanja organizacije sa promenama u okruženju, dok je strategijski menadžment kontinualan proces koji involvira kako planiranje i donošenje odluka, tako i realizaciju odluka i praćenje njihovih efekata na organizaciju.

Vojnoorganizacioni sistemi kao posebna vrsta organizacija koje egzistiraju u sferama vojne delatnosti predstavljaju pogodno tlo za primenu raznih vrsta menadžment disciplina, pa tako i strategijskog menadžmenta. Primena određenih sadržaja i podprocesa strategijskog menadžmenta u vojnoorganizacionim sistemima odavno postoji, ali se nije dovoljno obrađivala sa aspekta teorije menadžmenta i teorije organizacije, odnosno sam proces jeste obrađivan, ali nije se terminološko-metodološki određivao kao deo teorije menadžmenta, odnosno menadžmenta kao nauke.

Rad se sastoji iz tri pitanja koja daju jedinstvenu sliku strategijskog menadžmenta kao pojma, i specifičnosti njegove primene u vojnoorganizacionim sistemima. U prvom pitanju težište je dato na pojmovnom objašnjenju strategijskog menadžmenta, odnosno data je semantička analiza sintagme ,,strategijski menadžment”, kao i istorijska geneza strategijskog menadžmenta kao jedne od disciplina menadžmenta. Sadržaj, odnosno različiti modeli, koji su okvireni određenim fazama strategijskog menadžmenta, kao i njegovi podprocesi izloženi su u drugom pitanju. Specifičnosti primene strategijskog menadžmenta u vojnorganizacionim sistemima, prikazano je kroz pojmovno određenje vojnoorganizacionih sistema i kroz prizmu primera konkretne primene strategijskog menadžmenta u sistemu odbrane Republike Srbije, a obrađeno je u trećem pitanju.

\section{Pojam strategijskog menadžmenta i istorijski razvoj}

Pravilno komuniciranje sa drugim pojedincima i/ili grupama moguće je jedino upotrebom komunikabilnog jezika, što je od posebne važnosti za akademsku zajednicu, odnosno za grupe specijalista koje koriste naučni jezik i metode. Sledstveno tome, da bismo mogli dati, u potpunosti, i sa etiološkog stanovišta, prihvatljivo objašnjenje strategijskog menadžmenta, odnosno njegovog nastanka i istorijskog razvoja, trebamo prvo objasniti 
sam pojam strategijski menadžment, kako bi se potom mogla objasniti ina geneza. Pitanje je podeljeno na dve celine koje se nalaze u kauzalnom odnosu. U prvoj celini data je semantička analiza sintagme „,strategijski menadžment“, a u drugoj istorijska geneza strategijskog menadžmenta.

\section{Semantička analiza sintagme ,,strategijski menadžment“}

Sintagmu ,,strategijski menadžment“ čine dva pojma „,strategija“ i ,,menadžment“ sa različitim značenjem, pri čemu reč strategija ima denotativnu, a menadžment konotativnu ulogu u označavanju. U cilju nominalnog određenja navedene sintagme, neophodno je najpre odrediti značenje pojmova ,,strategija“ i ,,menadžment". Upotreba korelativnih termina za strategiju (najviši, vrhovni, ,,top“ nivo: znanja, vođenja, upravljanja; efikasnost u korišćenju raspoloživih resursa; jedinstven pravac delovanja i slično) u svakodnevnom životu je veoma česta pojava, i svi navedeni termini i sintagme, u načelu označavaju način (pristup ili metod) odnosno usmerenost za dostizanje određenih ciljeva. Međutim radi definisanja strategijskog menadžmenta kao posebne discipline u okviru menadžmenta, kao nauke, neophodno je što preciznije i egzaktnije odrediti obim i sadržaj navedenih termina, ali i ukazati na njihove distinkcije.

Sa semantičkog stanovišta reč strategija je zapravo kovanica dve grčke reči: ,,stratos" = vojska i ,,ago" = vodim. U vreme svog nastanka reč je označavala posao kojim su se bavili strategisti, odnosno najviši vojno-politički činovnici polisa (visoki službenici sa vojnim i civilnim kompetencijama), koji su međusobno bili rangirani shodno načelu primogeniture i ekonomske moći porodica iz kojih su poticali. Prvobitno značenje termina strategija je vremenom evoluiralo u skladu sa razvojem ljudskog znanja, ali i sa fenomenom geneze društvenih konflikata.

U modernom dobu, krajem 18. veka strategiju prvi put definiše, Žoli de Mesero u knjizi Teorija rata, koji naglašava: ,,da bi formulisala planove strategija razmatra odnos između vremena, prostora, sredstava i različitih interesa i svaki faktor uzima u obzir što je oblast dijalektike."1 Danas, strategija se koristi u svim sferama ljudske delatnosti od bezbednosti do ekonomije, pa shodno tome i pojmovno određenje termina nosi specifičnost delatnosti iz koje potiče, i ovde prezentujemo samo neke od administrativnih i akademskih definicija koje nam to i potvrđuju.

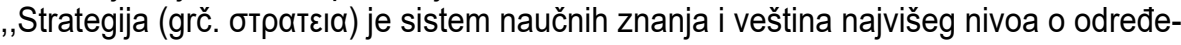
noj društvenoj delatnosti: sferi politike, vođenju rata i oružane borbe, ekonomskoj politici, diplomatiji i međunarodnim odnosima i drugo." ${ }^{2}$

Strategija je veština vođenja vojske i predstavlja glavnu disciplinu ratne veštine (vojne nauke). U svom prvobitnom etimološkom značenju strategija je označavala upotrebu vojske u ratu, sve dok se rat poistovećivao sa oružanom borbom.

Pripremanje i vođenje rata u celini, pojedinih njegovih etapa i usklađivanje strateških dejstava primarni je predmet proučavanja strategije kao grane vojne nauke. ${ }^{4}$

\footnotetext{
${ }^{1}$ Strachan, H., The lost mening of Strategy, Strategic Studies a Reader, Routledge, New York, 2008

${ }^{2}$ Larusova enciklopedija, L-Š, Vuk Karadžić, Beograd, 1978, str. 1689.

${ }^{3}$ Opšta enciklopedija, Jugoslovenski leksikografski zavod, Zagreb, 1982, str. 693.
} 
„Strategija ima trojako značenje: (1) skup postupaka za pokrete velikih ratnih jedinica od kojih zavisi uspeh u vojnom pohodu, i ratnih metoda čiji je cilj dobijanje rata; (2) metodika aktivnosti pojedinaca ili grupe koja treba da obezbedi što racionalnije ostvarenje postavljenih ciljeva i (3) skup pravila, principa i zakona, koji se koriste u donošenju dugoročnih upravljačkih akcija u funkciji sistema na koji se odnosi.“ ${ }^{5}$

lako se gotovo isključivo bavio pojmom strategije u okviru poslovnog sveta, Henri Mintzberg ukazuje kako je i u takvom redukovanom okviru strategija izuzetno složena i ambivalentna disciplina: „Moje istraživanje kao i istraživanja mnogih drugih pokazuje da je izrada strategije neverovatno složen proces koji obuhvata najsofisticiranije, najsuptilnije, a katkad i najpodsvesnije elemente ljudskog razmišljanja“. ${ }^{6}$ Poteškoća s definisanjem strategije je što ona, čak i u samo ovom kontekstu, ima različita značenja za različite ljude u organizaciji. Neki smatraju da strategiju predstavljaju planovi na visokom nivou koje smišlja upravljačka struktura. Drugi tvrde da strategija počiva na specifičnim i detaljnim aktivnostima koji se poduzimaju da bi se ostvarila željena budućnost. Trećima je pak strategija jednaka najboljoj praksi, dok je nekima strategija obrazac doslednosti aktivnosti tokom vremena. ${ }^{7}$ Potpuno je razumljivo, dakle, da će se poimanje strategije višestruko usložiti ukoliko u području obrane i bezbednosti strategiju počnemo razumevati izvan limita koje nameće logika poslovnog sveta.

Potrebe jedne organizacije strategija, u načelu zadovoljava na tri načina: (1) opisuje u kakvom su odnosu resursi organizacije i strategijsko okruženje; (2) obezbeđuje okvir za integrisanje aktivnosti organizacije u cilju jačanja njene konkurentske pozicije i (3) poznavanje metoda i tehnika za formulisanje strategije fokusira pažnju organizacije na isplative investicije i smanjuje broj potencijalno loših projekata.

„Strategija je planirana i ciljana pripravnost i koordinirana primena svih političkih, diplomatskih, privrednih, tehnoloških i naučno-intelektualnih (duhovnih) snaga jedne države kao i njenih vojnih snaga u miru, krizi i ratu." ${ }^{\prime 9}$

Za Milana Vujakliju u Leksikonu stranih reči i izraza termin strategija ima trojako značenje: (1) nauka o vođenju vojske, (2) veština ratovanja i (3) knjiga o veštini ratovanja. ${ }^{10}$

„,Strategija nije ni politika ni bitka, ona je najpre most koji povezuje politiku i bitku, odnosno može se reći da strategija nije ni veština niti nauka, ona je na određeni način i jedno i drugo. Veština kao stvaralačko umeće podrazumeva sposobnost da se misli strategijski kroz iskustvo, posmatranje i učenje." "11

Osnovni zadatak strategije je određivanje načina na koji će organizacija zadovoljiti dugoročne ciljeve uzimajući u obzir faktore okruženja i sopstvene sposobnosti. Dakle, strategija predstavlja vezu između organizacije i okruženja u kome funkcioniše ta organizacije, kao što je i prikazano na Slici $1 .{ }^{12}$

\footnotetext{
${ }^{4}$ Politička encikolpedija, Savremena administracija, Beograd, 1975, str. 1033.

${ }^{5}$ Kukoleča, S., Organizaciono-poslovni leksikon, Rad, Beograd, 1986, str. 461.

${ }^{6}$ Mintzberg, H. ,The Rise and Fall of Strategic Planning. U: Harvard Business Review, January-February, 1994. Preuzeto s: https://hbr.org/1994/01/the-fall-and-rise-of-strategic-planning

${ }^{7}$ Niven, P. R., Balanced scorecard: Korak po korak: Maksimiziranje učinka i održavanje rezultata. Poslovni dnevnik: Masmedia, Zagreb, 2007., str. 115.

${ }^{8}$ Walker, G., Modern Compettive Strategy, International Edition, McGraw-Hill, New York, 2007

${ }^{9}$ Erich, E., Definition und Gebrauch des Begriffes Strategie, Österreichische Militarische Zeitshrift, No 2, 1998.

${ }^{10}$ Vujaklija, M., Leksikon stranih reči i izraza, Prosveta, Beograd, 1980, str. 876.

${ }^{11}$ Gray, C. S., Why strategy is difficult, Strategic Studies a Reader, Routledge, New York, 2008.

${ }^{12}$ Petrović, D., i drugi, Menadžment i organizacija, Fakultet organizacionih nauka, Beograd, 2011, str. 435.
} 


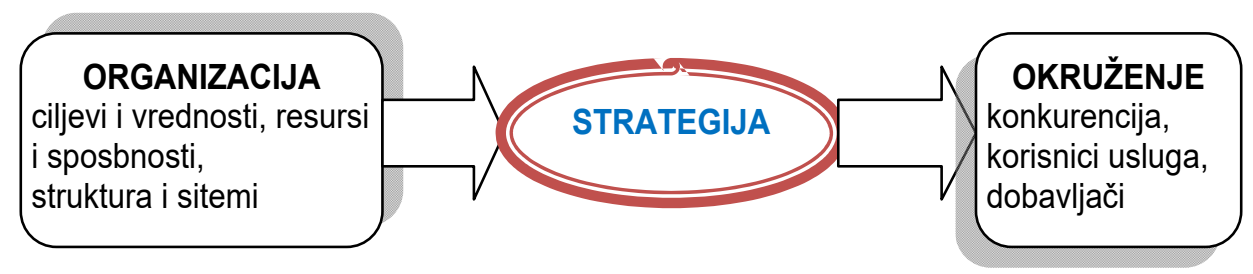

Slika 1 - Definisanje strategije

Jedan od najraširenijih i najpopularnijih modela strategije je ends, ways, means model. S obzirom da se strategija vrlo često koristi kao opšti pojam za plan, koncept, smer delovanja ili tek „ideju“ za taj smer, ovaj model ide za sužavanjem toga značenja te strategiju prvenstveno smatra područjem interesa i delovanja lidera najviših upravljačkih nivoa - države, vojske, poslovnih korporacija ili neke druge institucije, u zavisnosti od toga o kojoj se strategiji radi. ${ }^{13}$ Henry Ekles, na primer, opisuje strategiju kao ..."sveobuhvatni smer delovanja na upravljanju situacijom i predmetnim područjem, kako bi se ostvarili ciljevi“. ${ }^{14}$ Proizlazi kako je za strategiju presudno nekoliko stvari: ona je sveobuhvatna, ona utvrđuje smer delovanja, njena svrha je upravljanje te se odnosi na primenu moći. Primenjujući strategiju na područje države, odnosno, nacionalnih interesa, možemo reći kako je strategija upotreba instrumenata (elemenata) moći (političkih, diplomatskih, ekonomskih, vojnih, informacijskih) kako bi se ostvarili politički ciljevi države u saradnji ili pak kroz takmičenje s drugim akterima. ${ }^{15}$

Semantička analiza termina menadžment (eng. management) nam govori da sam termin vodi poreklo od dve latinske reči, ,,manum" = ruka i ,,agree" = voditi. Termin menadžment se prvi put pojavljuje krajem 19. veka u zemljama Zapadne Evrope, međutim menadžment se u nauci pojavljuje tek početkom 20. veka, tačnije 1903. godine, u knjizi Upravljanje pogonom (Shop Management) od Frederika Tejlora ${ }^{16}$ (1856-1917), koji se smatra jednim od utemeljivača menadžmenta kao nauke.

$U$ našem jeziku ne postoji odgovarajući termin za englesku reč management, te se shodno tome i različito prevodi, terminološki određuje i suštinski shvata. Naime, u našem jeziku menadžment se uglavnom prevodi kao upravljanje ili rukovođenje. Ovde treba istaći, da se termin upravljanje, odnosi na sisteme uopšte, dok se menadžment neposred-

\footnotetext{
${ }^{13}$ Domjančić, S., Gracin, D. Kako promišljati strategiju u području sigurnosti i obrane? Polemos, Vol. XIX, br. 37, Zagreb, 2016., str. 102-103.

${ }^{14}$ Eccles, H., Military Concepts and Philosophy. New Brunswick, N.J.: Rutgers Univ. Press, 1965., pp. 48.

${ }^{15}$ Yarger, Richard H., Towards A Theory of Strategy: Art Lykke and the Army War College Strategy Model. Preuzeto s: http://www.au.af.mil/au/awc/awcgate/army-usawc/stratpap.htm, 2008.

${ }^{16}$ Frederik Tejlor je počeo kao običan radnik u čeličani, ali je uspeo da i pored teških uslova rada postane mašinski inženjer. Radni vek je proveo u Midvejl čeličanama u SAD, i dao je enorman doprinos unapređenju organizacije rada, i to kroz normiranje i oblikovanje radnog mesta. Tejlor se bavio analizom i poboljšanjem efikasnosti rada na svakom pojedinačnom radnom mestu. Pored Upravljanja preduzećem, Tejlor objavljuje studiju Sistem plaćanja po komadu (A Piece-rate System) 1895. godine i knjigu Principi naučnog upravljanja (The Principles of Scientifc Managemenet) 1911. godine, po kojoj se dela čitave generacije teoretičara menadžmenta (H. Ford, H. Emerson, F. i L. Gilbert, H. Gant i drugi) nazivaju klasična škola ili naučna teorija menadžmenta.
} 
no odnosi na organizacione sisteme, a rukovođenje predstavlja usklađivanje i usmeravanje prevashodno ljudskih resursa, te samim time možemo rezimirati da oba sinonima ne odgovaraju tačnosti značenja termina menadžment.

U literaturi menadžmentu se daje višestruko značenje: (1) izjednačava se sa poslom koji menadžer obavlja u organizaciji, (2) poistovećuje se sa upravom preduzeća i (3) podrazumeva određeni nivo znanja o upravljanju. Menadžment je zapravo kohezija rada pojedinca i/ili tima, izabranog i/ili dodeljenog cilja i ograničenih resursa na efikasan i efektivan način.

U Leksikonu stranih reči i izraza ne postoji objašnjenje termina menadžment, već samo termina menadžer pod kojim se podrazumeva: nadzornik pozornice, reditelj, režiser, tehnički upravnik ili direktor u engleskim fabrikama, poslovođa, priređivač, npr. neke sportske utakmice, javne priredbe i slično. ${ }^{17}$

,,U kontekstu reči menadžment obično se koriste termin sa značenjem upravljati, rukovoditi, raspolagati nečim. Neki jezici za taj pojam nemaju odgovarajuću reč, a neki društveno-politički sistemi negiraju ga i praktično zabranjuju, pa umesto njega koriste sinonime kao što su: odlučivati, regulisati, planirati, kontrolisati, organizovati, vladati, postizati ciljeve, rukovoditi, motivisati, sprovoditi..."18

Prema Piteru F. Drakeru, menadžment je društvena tehnologija i u njegov definicioni okvir ulazi sve što on čini, odnosno menadžment može da se opiše i definiše samo preko funkcija koje obavlja. Džejms Stoner, Daniel R. Gilbert Junior i Robert Edvard Frimen smatraju da je menadžment proces koji se sastoji od planiranja, organizovanja, vođenja, kontrolisanja poslova članova organizacije i korišćenja svih raspoloživih sredstava organizacije da se postignu naznačeni ciljevi.

Slično stanovište imaju i Ketrin Bartol i Dejvid Martin koji menadžment vide kao proces kojim se ostvaruju organizacioni ciljevi obavljanja četiri osnovne funkcije: planiranje, organizovanje, vođenje i kontrola. Ričard Daft smatra da menadžment omogućava postizanje organizacionih ciljeva na efektivan i efikasan način kroz planiranje, organizovanje, vođenje i kontrolu organizacionih resursa. ${ }^{20}$

Menadžment se kao pojam, i u teorijskom i praktičnom smislu, može posmatrati i definisati kroz tri posebna aspekta: (1) kao proces upravljanja određenim poslovima, poduhvatima ili sistemima radi efikasnijeg i efektivnijeg dostizanja zajedničkih ciljeva; (2) kao posebna grupa ljudi čiji je posao da upravljaju izvršavanjem poslova i zadataka koje obavljaju drugi ljudi, radi efektivnog i efikasnog dostizanja predviđenih zajednički ciljeva i (3) kao posebna naučna disciplina, multidisciplinarnog karaktera, koja se bavi istraživanjem problema upravljanja određenim poslovima, poduhvatima i društvenim sistemima. ${ }^{21}$

$\mathrm{Na}$ osnovu rezimiranja navedenih definicija možemo konstatovati da nema opšte prihvaćene definicije menadžmenta i da se termin menadžment najčešće vezuje za pojam upravljanja određenim poslom, poduhvatima i sistemom. Međutim jedna definicija, koju je

\footnotetext{
${ }^{17}$ Vujaklija, M., Isto, str. 550.

${ }^{18}$ Adižes, I., Upravljanje promenama, ASEE, Novi Sad, 2008

${ }^{19}$ Ilić, G., Osnovi menadžmenta, Poljoprivredni fakultet, Banja Luka, 2005, str. 95.

${ }^{20}$ llić, G., Isto, str. 96-97.

${ }^{21}$ Jovanović, P., Obradović, V., Petrović, D., Mihić, M., Jovanović, A., Crosscultural aspects of project management: Serbia goes to Iraq for Jordan project, International Journal of Industrial Engineering, 16(4), 2009.
} 
dao jedan od pionira menadžmenta Anri Fajol ${ }^{22}$ (1841-1925), najviše se koristila, ali se i danas koristi. Prema Fajolu, menadžment predstavlja proces predviđanja, organizovanja, komandovanja, koordinacije i kontrole. To je proces ili funkcija koja je najznačajnija za svako preduzeće i ona obuhvata poslove upravljanja preduzećem. Klasifikacija menadžmenta može se vršiti pomoću različitih kriterijuma; opšte prihvaćena klasifikacija, koja ujedno i definiše termin menadžment prikazana je na slici 2 . $^{23}$

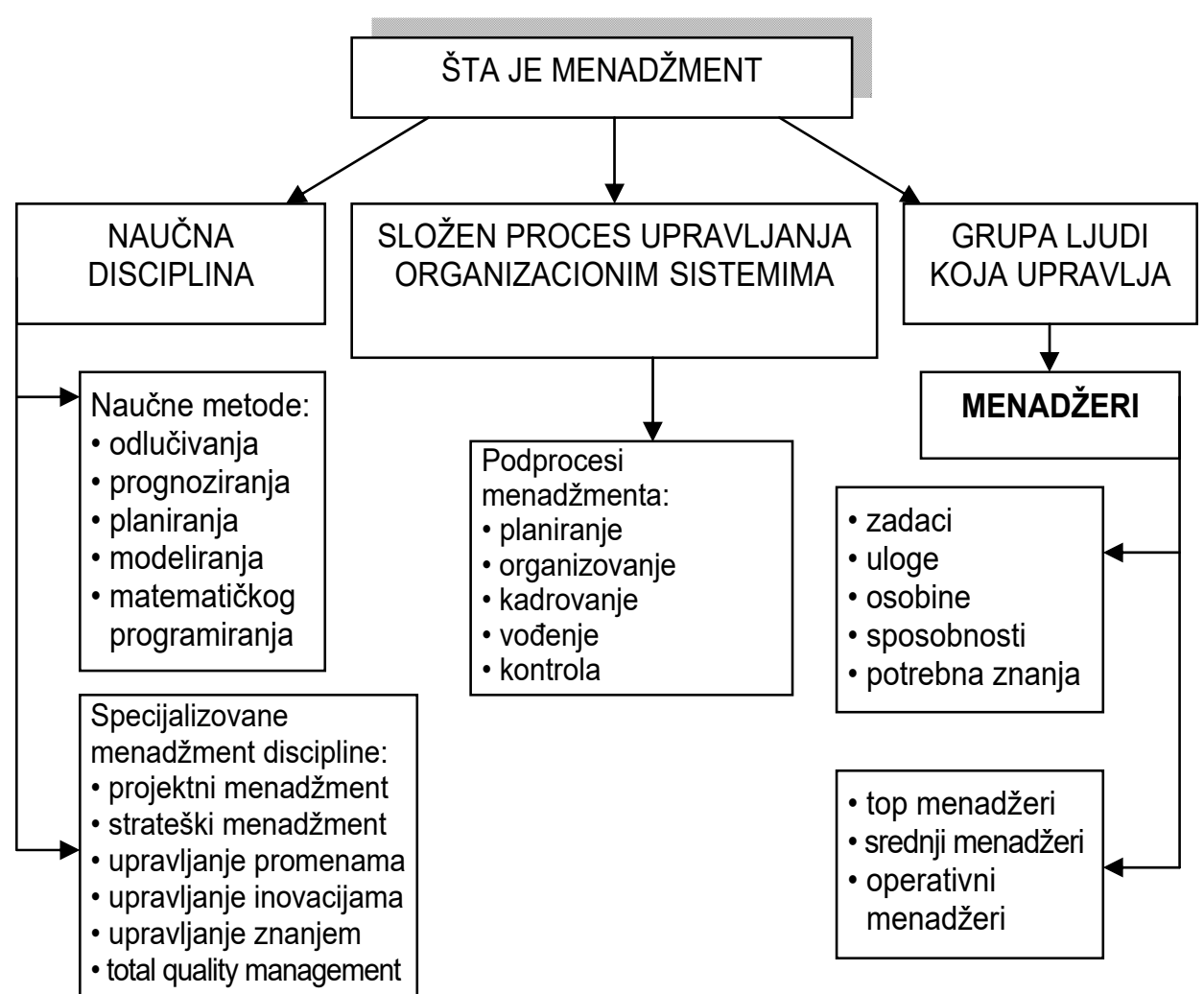

Slika 2 - Klasifikacija (definisanje) menadžmenta

\footnotetext{
${ }^{22}$ Anri Fajol je po profesiji bio rudarski inženjer, živeo je i radio u Francuskoj. Fajol je bio savremenik F. Tejlora i takođe se bavio problematikom povećanja efikasnosti rada. Međutim, nije se u potpunosti slagao sa principima koje je zastupao Tejlor, već je smatrao da se efikasnost rada može poboljšati jedino rešavanjem globalnih problema organizacije i upravljanja preduzećem. Svoje stavove izložio je u knjizi Opšte i industrijsko upravljanje, 1916. godine. Smatra se tvorcem i zastupnikom jednog od pravaca u klasičnoj teoriji meandžmenta koji se naziva ,,administrativna doktrina“.

${ }^{23}$ Jovanović, P., Živković, D., Jovanović, F., Menadžment i projektni menadžment, Visoka škola za projektni menadžment, Beograd, 2008, str. 5.
} 
U literaturi takođe, ne postoji jedna, opšte prihvaćena definicija strategijskog menadžmenta, ali na osnovu prethodnih semantičkih, etioloških i etimoloških razmatranja možemo uvideti da strategijski menadžment predstavlja jednu multi-disciplinarnu naučnu disciplinu koja ističe značaj odnosa organizacije i njenog okruženja, kao i koordinacije različitih funkcionalnih celina organizacione strukture, a sve u kontekstu ostvarenja definisanih ciljeva u budućnosti, u skladu sa raspoloživim resursima organizacije.

\section{Istorijska geneza strategijskog menadžmenta}

Kada govorimo o nastanku strategijskog menadžmenta kao jedne od modernih disciplina menadžmenta trebamo prvo nešto reći o nastanku samog menadžmenta kao društvene pojave, aktivnosti, odnosno procesa. Istorijska geneza menadžmenta nam pokazuje da je menadžment zapravo oduvek postojao kao nešto što ljudi spontano čine. Početkom menadžmenta smatra se prvo organizovanje ljudi u grupe zarad nekog cilja (skupljanja hrane, izgradnja skloništa, izrada oruđa za rad, izrada odevnih predmeta i slično). Smisao za menadžment se posebno ističe kod monumentalnih građevina najstarijih civilizacija, sledstveno tome možemo reći da je menadžment kao praktična delatnost, star koliko i ljudsko društvo.

Međutim, pojava menadžmenta u modernom dobu počinje početkom 19. veka za vreme fenomena, koji je u ekonomiji poznat kao ,industrijski odnosi“. Sintagma industrijski odnosi označava period evolucije socio-ekonomskih odnosa u poslovnom okruženju prouzrokovana opštim naučno-tehnološkim razvojem (otkrićima). Nosioci, odnosno osnovni činioci industrijskih odnosa bili su: (1) vlasnici kapitala - poslodavci, (2) menadžeri, (3) sindikati i (4) radnici (zaposleni). ${ }^{24}$

U Engleskoj se 1907. godine, prvi put u modernoj istoriji pojavljuju profesionalni menadžeri, i to kao direktna posledica razdvajanja privatnog (najčešće porodičnog) vlasništva nad kompanijama od upravljačkih funkcija, odnosno vlasnici kompanija nisu više bili i menadžeri. Ovim činom vlasnik kompanije postaje poslodavac i upravljačkim strukturama i radnicima (zaposlenima). Industrijski odnosi i razvoj organizacione strukture poslovnih organizacija ubrzano su doveli do legitimizacije i legalizacije menadžmenta u pogledu vlasti, a samim time i moći. Sledstveno tome, nastaje „,doba menadžmenta“ koje traje i danas, ali specifikumom modernog menadžmenta se ogleda u dve stvari: (1) postojanje velikog broja pojavnih oblika menadžmenta, odnosno menadžment disciplina i (2) broj pojavnih oblika nije konačan, već se on uvećava u skladu sa pojavom inovativnih ljudskih delatnosti.

Hronološki gledano, a shodno primeni menadžmenta kao prevashodno upravljačke i pragmatične ljudske delatnosti, genezu menadžmenta možemo podeliti u pet perioda. Prvi period je od antičkih civilizacija do 1880. godine, i čine ga istorijski izvori i iskustva iz ove oblasti.

Drugi period je od 1880. do 1930. godine, period koji se naziva i ,,doba prvih savremenih menadžera". Karakteristika drugog perioda je enorman porast industrijske proizvodnje na bazi naučno-tehnoloških otkrića, i period kada vlasnici fabrika poveravaju kom-

\footnotetext{
${ }^{24}$ Nabrajanje činilaca industrijskih odnosa je dato u skladu sa vertikalnom hijerarhijom i međusobnim odnosima.
} 
pletnu proizvodnju posebno obučenim ljudima koji zastupaju njihove interese - menadžerima. Usled velikog broja fabrika i porasta broja menadžera pojavila se potreba za obučavanjem, odnosno školovanjem menadžera, pa u ovom periodu nastaje i prva naučna teorija, odnosno klasična ili ,,naučna“ škola menadžmenta koja je imala više pravaca.

Treći period je do 1930. do 1950. godine, u ovom periodu još uvek se osećaju uticaji ratnih užasa iz Drugog svetskog rata, pa se sledstveno tome javlja pojačano interesovanje za ljude i/ili grupe ljudi i radi se mnogo na motivaciji radnika. U organizacionoj teoriji ovaj period se naziva i bihevioristički pravac, neoklasična škola ili ,,škola međuljudskih odnosa“.

Četvrti period je od 1950. godine do 1990. godine. U ovom periodu sistematizuju se i uopštavaju dosadašnja teorijska iskustva. U teoriju organizacije i menadžmenta uvodi se sistemski pristup, javljaju se situacione i kontignetne teorije, istražuju se problemi upravljanja institucijama i organizacijama sutrašnjice, nagoveštava se internacionalizacija menadžmenta i slično. ${ }^{25}$

Peti period je nastao 1990. godine i danas je aktuelan. U teoriji menadžmenta ovaj period se naziva i , upravljanje u Novom društvu“ prema knjizi istoimenog naziva od jednog od najpoznatijih teoretičara menadžmenta, ali i organizacije, Pitera F. Drakera. Karakteristika ovog perioda je na razvijanju novih pristupa i koncepata u menadžmentu sa tendencijom da neki postanu paradigme ${ }^{26}$, a tu spadaju: (1) upravljanje u novom društvu, (2) teorija haosa, (3) organizacija koja uči, (4) reinženjering poslovnih procesa, (5) menadžment totalnog kvaliteta, (6) upravljanje promenama i (7) menadžment znanja.

Strategijski menadžment nastaje u četvrtom periodu razvoja menadžmenta, preciznije 50-tih i 60-tih godina 20. veka. Nastanak strategijskog menadžmenta je bio uslovljen potrebama poslovne prakse, naročito u domenu finansijskog planiranja i budžetiranja, a ne razvoja teorijskog pristupa, odnosno unapređenja postojećih koncepata menadžmenta. Prvi radovi iz ove specijalizovane menadžment discipline bili su Strategija i struktura od Alfreda Čendlera iz 1962. godine i Strategija preduzeća Igora Ansofa iz 1965. godine.

Težišni problem menadžera tog doba bila je koordinacija odluka i proces kontrole usled složenosti poslovnog okruženja i veličine preduzeća. Sledstveno tome, javlja se strategija kao najvažniji dokument planiranja, i bazira se, uglavnom, na petogodišnjim planskim dokumentima koji, u načelu, obuhvataju: (1) skup ciljeva, (2) prognozu finansijskih parametara (prihode, troškove proizvodnje, učešće na tržištu, zahteve tržišta i slično), (3) prioritete u proizvodnji i (4) rasporede i procene kapitalnih ulaganja. Na osnovu strategije kao dokumenta na kojem počiva menadžment i organizacija preduzeća, jedna nova specijalizovana menadžment disciplina dobija svoje ime, jer naposletku strategija je u svojoj esenciji zapravo bila, a to je uglavnom i danas, ideja menadžera. Većina organizacija je imala/ima adekvatne mehanizme za implementiranje ideja menadžera u određene strategije.

Strategija preduzeća se definiše kao skup pravila odlučivanja i vodič koji vodi preduzeće u budućnost radi dostizanja budućih ciljeva preduzeća. Ovi skupovi pravila odlučivanja se odnose na ponašanje preduzeća u promenjivoj okolini. ${ }^{27}$ Evolucija strategijskog menadžmenta se u velikoj meri poklapa sa razvojem pristupa u definisanju strategije. $U$ Tabeli 1 prikazana je evolucija strategije shodno dominantnim temama. ${ }^{28}$

\footnotetext{
${ }^{25}$ Damjanović, M., Menadžerska revolucija, Prosveta, Beograd, 1990, str. 39.

${ }^{26}$ Grč. paradeigma - primer za ugled, obrazac, uzorak, uzor.

${ }^{27}$ Ansoff, H., I., Corporate Strategy, Penguin Books, London, 1987.

${ }^{28}$ Grant, R., Contemporary Strategy Analysis, VI Edition, Blackwell Publishing, Oxford, 2007.
} 
Tabela 1 - Razvoj strategije sa dominantnim temama

\begin{tabular}{|c|c|c|}
\hline $\begin{array}{l}\text { Vreme trajanja } \\
\text { primene strategije }\end{array}$ & $\begin{array}{c}\text { Naziv } \\
\text { strategije }\end{array}$ & $\begin{array}{c}\text { Dominantne } \\
\text { teme u okviru strategije }\end{array}$ \\
\hline $1950-1960$. & FINANSIJSKO BUDŽETIRANJE & $\begin{array}{l}\text { 1. Finansijsko planiranje i kontrola; } \\
\text { 2. Procena kapitalnih ulaganja } \\
\text { putem diskontovanja }\end{array}$ \\
\hline 1960-1970. & KORPORATIVNO PLANIRANJE & $\begin{array}{l}\text { 1. Srednjeročne ekonomske } \\
\text { prognoze; } \\
\text { 2. Formalni planovi; } \\
\text { 3. Diversifikacija; } \\
\text { 4. Službe za strateško planiranje }\end{array}$ \\
\hline 1970-1980. & STRATEŠKO POZICIONIRANJE & $\begin{array}{l}\text { 1. Analiza industrije; } \\
\text { 2. Segmentacija tržišta; } \\
\text { 3. Kriva iskustva; } \\
\text { 4. PIMS analiza; } \\
\text { 5. Portfolio menadžment }\end{array}$ \\
\hline 1980-1990. & KONKURENTSKA PREDNOST & $\begin{array}{l}\text { 1. Analiza resursa i internih } \\
\text { sposobnosti; } \\
\text { 2. Restrukturiranje i reinženjering; } \\
\text { 3. Alijanse }\end{array}$ \\
\hline 1990-2000. & $\begin{array}{c}\text { STRATEGIJA ZA NOVU } \\
\text { EKONOMIJU }\end{array}$ & $\begin{array}{l}\text { 1. Strateške inovacije; } \\
\text { 2. Novi poslovni modeli; } \\
\text { 3. Tehnološke inovacije; } \\
\text { 4. Povećanje akcionarskog kapitala }\end{array}$ \\
\hline $\begin{array}{l}\text { od 2000. godine } \\
\text { u primeni }\end{array}$ & STRATEGIJA U NOVOM VEKU & $\begin{array}{l}\text { 1. Društveno odgovorno poslovanje; } \\
\text { 2. Poslovna etika; } \\
\text { 3. Globalne strategije; } \\
\text { 4. Nepredvidiva tržišta }\end{array}$ \\
\hline
\end{tabular}

Ovde je bitno istaći i da svaka od navedenih strategija ima svoj nivo organizacije na kojem se primenjuje, pa tako imamo: (1) korporativne, (2) poslovne i (3) funkcionalne strategije. ${ }^{29}$ Navedena klasifikacija strategija po nivoima organizacije uvažava različite nivoe menadžmenta: (1) vrhovni-top menadžment, (2) srednji i (3) operativni, odnosno određeni nivo strategije precizira koji nivo menadžmenta određenu strategiju definiše i operacionalizuje.

U odnosu na većinu autora koji razlikuju tri nivoa strategije, Kejmford i Kalagam uvode i četvrti nivo, tj. društvenu strategiju. Ova vrsta strategije je fokusirana na zahteve društva i traži adekvatne načine reagovanja na izazove društvene sredine. Autori smatraju da je društvena strategija, neophodna preduzećima koja imaju brojne i kompleksne odnose sa institucijama društva, jer suštinski pomaže proces integrisanja u društveni kontekst. $^{30}$

\footnotetext{
${ }^{29}$ Funkcionalne strategije se primenjuju za određene funkcije u preduzeću: marketing, proizvodnja i drugo.

${ }^{30}$ Petrović, D., i drugi, Isto, str. 438.
} 
Evolucija strategijskog menadžmenta ima svoje četiri etape ili prema jednom delu autora četiri koncepta: (1) osnovno finansijsko planiranje, (2) planiranje zasnovano na predviđanju, (3) strategijsko planiranje i (4) strategijski menadžment. Prva etapa je esencija strategijskog menadžmenta i trajala je od 1950. do 1960. godine, osnovna obeležja ove etape već smo istakli u prethodnom delu rada.

Druga etapa je trajala od 1960. do 1970. godine i osnovno obeležje je dugoročno planiranje i kreiranje dugoročne poslovne politike. Centralna tema u ovoj etapi je bila diversifikacija u korporativnom planiranju. Osnovni nedostatak je bio striktno pridržavanje planovima, odnosno definisanim ciljevima, čije je ostvarenje u velikoj meri zavisilo od finansijskih uspeha, odnosno neuspeha, a kako u to vreme nije postojala adekvatna kontrola planova na nivou organizacije, planiranje se lociralo isključivo na nivou top menadžmenta, odnosno ovde započinje primena jednog od pristupa u planiranju - ,,odozgo na dole".

Treća etapa nastaje na bazi dugoročnog planiranja, ali se fokusira na analizu okruženja i donošenje odluka koje će uvažiti identifikovane rizike i neizvesnosti koje nosi budućnost. Strategijsko planiranje je nastalo iz potrebe za aktivnim reagovanjem na promene u okruženju. Treća etapa je trajala od 1970. do 1990. godine.

,Za razliku od koncepata dugoročnog planiranja, strategijsko planiranje je kompleksniji proces, jer zahteva više vremena i uključuje sagledavanje tržišnih, društveno-političkih, pravnih, ekonomskih, socijalnih i tehnoloških uslova, kao i izvora koji vode specifičnim mogućnostima i opasnostima u okruženju. Iz tog razloga, u proces stvaranja strategijskih planova organizacije i definisanje pravaca akcije neophodno je uključiti analizu informacija iz eksterne i interne sredine. ${ }^{\text {*31 }}$

Četvrta etapa razvoja strategijskog menadžmenta nastaje 90 -tih godina 20 . veka i traje i danas. Pod uticajem globalizacije (mondijalizacije) sveta, enormno brzim razvojem nauke, tehnike i tehnologije, skraćivanjem životnog ciklusa proizvoda, stvara se klima uslova za modifikaciju strategijskog planiranja i njegovu evoluciju u viši nivo - strategijski menadžment ili strateški menadžment prema jednom delu autora.

Naime, tokom 80-tih i 90-tih godina 20 . veka kod većine organizacija javlja se potreba za usavršavanjem postojećeg načina planiranja u skladu sa novim trendovima u okruženju, odnosno javlja se potreba za efikasnijom kontrolom, implementacijom i evaluacijom strategija organizacija. Direktna posledica navedenih potreba jeste nastajanje strategijskog menadžmenta, koji sa određenim varijacijama postoji i danas. Ovim promenama strategijsko planiranje je postalo samo podproces strategijskog menadžmenta kako je to i prikazano na slici 3.

Osnovne karakteristike četvrte etape su: (1) donošenje strateških odluka je isključivo u nadležnosti vrhovnog menadžmenta i zahteva analizu uticaja faktora iz okruženja kao eksternog, tako i internog; (2) uticaj strateških odluka je dugoročan; (3) strategija organizacije je u korelaciji sa definisanim ciljevima; (4) strategija je u funkciji ostvarenja ciljeva; (5) stepen efikasnost sprovođenja strategije direktno je proporcionalan kvalitetu odnosa organizacije sa zainteresovanim stranama i (6) strategijskim menadžmentom je ostvaren interaktivni odnos organizacije i eksternog okruženja.

\footnotetext{
${ }^{31}$ Petrović, D., i drugi, Isto, str. 438.
} 


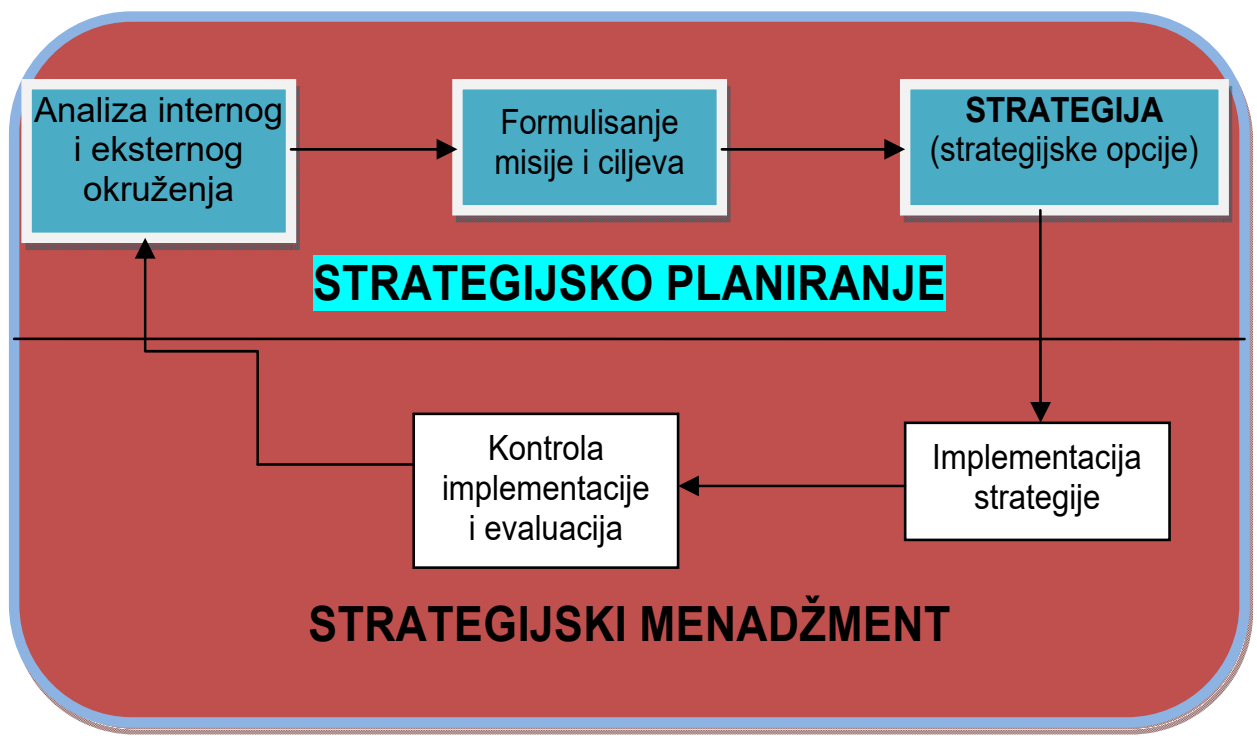

Slika 3 - Strategija, strategijsko planiranje i strategijski menadžment ${ }^{32}$

„,Strateški menadžment uvodi pojam strategije kao načina za rešavanje budućih situacija i problema, kao svojevrsnog vodiča preduzeća u budućnost. Strateški menadžment se bavi budućnošću preduzeća, njegovom pozicijom i poslovanjem i podrazumeva definisanje ciljeva koje preduzeće želi u budućnosti dostići i pravce i načine dostizanja ovih ciljeva, što i predstavlja strategiju. ${ }^{33}$

\section{Sadržaj i funkcije strategijskog menadžmenta}

Strategijski menadžment je proces u kojem participira celokupna organizaciona struktura na svim nivoima, pa sledstveno tome dolazi do definisanja ili formiranja više strategija kojima se žele postići rezultati različitog značaja, u zavisnosti od kriterijuma i načina (metoda) definisanja. Shodno činjenici da je strategijski menadžment kontinuiran i iterativan proces, odvijanje ovog procesa može se predstaviti kroz određeni broj sadržaja (faza) i funkcija (podprocesa).

Ovo pitanje obrađujemo kroz dve celine, u prvoj posebno objašnjavamo sadržaje ili prema jednom delu autora, modele strategijskog menadžmenta, koji se uokviruju fazama planiranja i implementacije strategije, dok u drugoj celini predstavljamo funkcije ili podprocese strategijskog menadžmenta.

${ }^{32}$ Mihić, M., Koncept upravljanja organizacijom integrisanjem strateškog i projektnog menadžmenta, doktorska disertacija, Fakultet organizacionih nauka, Beograd, 2008

${ }^{33}$ Jovanović, P., Menadžment-teorija i praksa, Fakultet organizacionih nauka, Beograd, 2005, str. 268. 


\section{Sadržaj strategijskog menadžmenta}

Rezultati strategijskog menadžmenta, kao procesa su: (a) odluke, (b) naređenja i (v) akcije proistekle iz odgovarajućih analiza, metodologija odlučivanja (procesa donošenja odluka) i planova. Da bi rezultati strategijskog menadžmenta pomogli u dostizanju planiranih ciljeva potrebno je permanentno pratiti sprovođenje strategije i vršiti evaluaciju dobijenih rezultata. Iskustvo iz prakse je pokazalo da je mnogo važnije, a samim time teže implementirati strategiju u konkretne situacije u internom i eksternom okruženju, od sposobnosti da se strategija formuliše.

,Istraživanja pokazuju da je stopa neuspeha strategija između 70\% i 90\%. Takođe, procene američkih top menadžera i konsultanata pokazuju da najveći deo problema (oko $70 \%$ ) nije posledica loše strategije, već njene implementacije." ${ }^{34}$ Iz tog razloga tokom evolucije strategijskog menadžmenta nastalo je više modela strategijskog menadžmenta koji se ogledaju u postojanju određenog broja faza koje mogu, u načelu, da se grupišu u sledeće segmente: (1) planiranja i strategijske analize, (2) implementacije strategije, (3) praćenje i kontrola implementacije strategije. Ovde ćemo predstaviti nekoliko najpoznatijih i u praksi najupotrebljivanih modela strategijskog mendžmenta.

Strategijski menadžment se može predstaviti kao iterativan proces koji uključuje: (1) analizu sredine, (2) usmeravanje organizacije ili misija i ciljeva, (3) formulisanje strategije, (4) implementacija strategije i (5) strategijska kontrola. ${ }^{35}$ Sličan, ali jednostavniji model koji se i danas upotrebljava, predstavljen je 1999. godine, ima samo tri faze: (1) strategijska analiza, (2) strategijski izbor i (3) primena strategije. Ovaj model prikazan je na slici $4 .{ }^{36}$

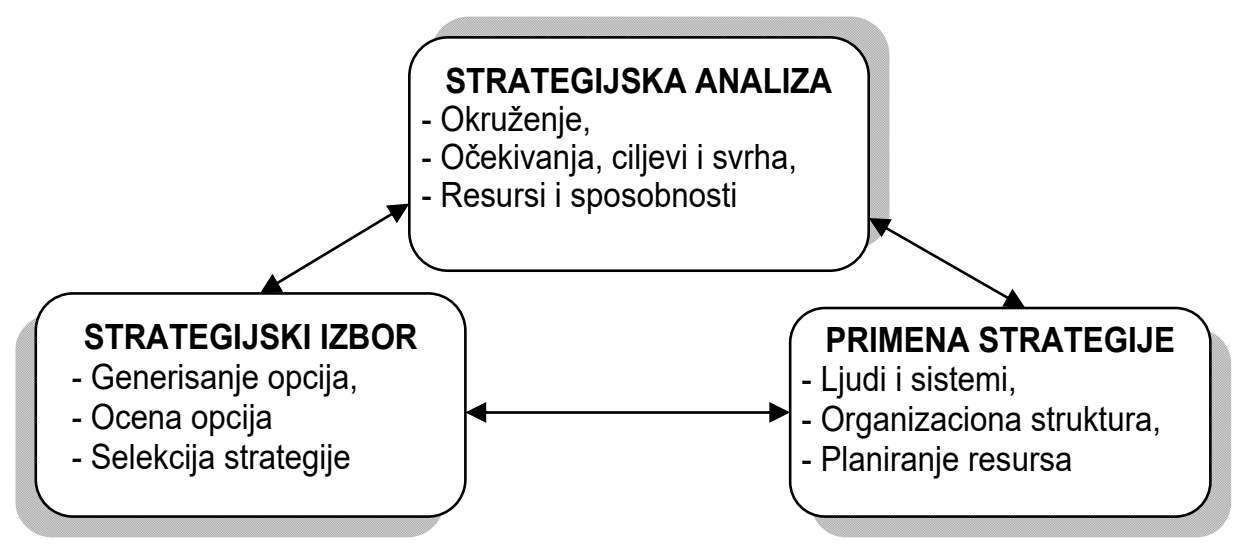

Slika 4 - Model strategijskog menadžmenta iz 1999. godine

\footnotetext{
${ }^{34}$ Đuričin, D., Janošević, S., Menadžment i strategija, Ekonomski fakultet, Beograd, 2005.

${ }^{35}$ Certo, S., P., Strategic Management: Concepts and Applications, McGraw-Hill, New York, 1991.

${ }^{36}$ Johnson, G., Scholes, K., Exploring Corporate Strategy, Prentice-Hall, New Jersey, 1999.
} 
Međutim, pre desetak godina definisan je jedan od najmodernijih modela strategijskog menadžmenta koji se bazira na prethodno prikazanom modelu, ali ga detaljnije razrađuje. Osnovne faze ovog modela su: (1) misija organizacije, (2) interna i eksterna analiza, (3) strategijska analiza i izbor, (4) dugoročni ciljevi, (5) korporativna i poslovna strategija, (6) kratkoročni ciljevi, (7) funkcionalne taktike - programi i paketi, (8) politike, (9) implementacija - restruktuiranje, reinženjering, re-fokusiranje organizacije, (10) strategijska kontrola i kontinualno unapređenje.

U našoj literaturi dominira model koji, takođe predstavlja modifikovanu verziju modela iz 1999. godine. ,,Strateški menadžment obuhvata sledeće osnovne faze: (1) stratešku analizu, (2) predviđanje budućnosti, (3) definisanje misije i strateških ciljeva, (4) formulisanje i izbor strategije, (5) primenu strategije i (6) kontrolu primene strategije."

Strateška analiza predstavlja analizu okruženja organizacije, i u načelu obuhvata dve analize: (1) internog i (2) eksternog okruženja. Interno okruženje predstavljaju unutrašnje (interne) mogućnosti organizacije da prihvati ili se odupre uticajima okoline, a analiza eksternog okruženja treba da prezentuje okolinu u kojoj organizacija egzistira i analizu uticaja koje okolina vrši na organizaciju. Za analizu okruženja često se primenjuje SWOT ${ }^{39}$ analiza. Naime, snage treba usmeriti ka iskorišćavanju šansi ili minimiziranju opasnosti, a s druge strane, uočene ili otkrivene slabosti treba minimizirati da bi se iskoristile šanse ili smanjile opasnosti koje dolaze iz okruženja. Takođe, zadatak SWOT analize je da otkrije i latentne potencijale organizacije kao što su informacije, znanje, istraživačke veštine i slično.

Međutim, kada govorimo o uticajima okruženja u kontekstu strateške analize, trebamo uzeti u obzir i da se okruženje sastoji od većeg broja faktora. Shodno uticaju faktora okruženja na organizaciju, okruženje možemo podeliti i na: (1) direktno ili neposredno i (2) indirektno ili posredno. Direktno okruženje čine sledeći faktori: (a) korisnici usluga, (b) konkurencija, (v) sindikati, (g) aktivnosti izvršne vlasti, (d) rad finansijskih institucija, (đ) mediji, nevladine organizacije i drugi.

Interakcijom faktora indirektnog okruženja formira se makro okruženje, a faktori indirektnog okruženja su: (a) politički, (b) ekonomski, (v) socijalni i (d) tehnološki. Najčešće korišćeni alat za analizu makro okruženja je PEST analiza čiji je naziv akronim navedenih faktora. Faktori PEST analize imaju jak uticaj i na definisanje strategije, jer su oni van organizacije i mogu se posmatrati u kontekstu šansi, ali i pretnji. Ovde treba istaći da se makro-ekonomski faktori razlikuju prema geografskoj pripadnosti organizacije, odnosno prema kontinentima, regionima i državama u kojima organizacije egzistiraju. Postoje i proširene forme ove analize, kao što su BPEST analiza (B-poslovni faktori) i SPESTLE (S-bezbednosni, L-zakonski faktori i E-ekološki faktor).

Kada govorimo o analizi eksternog okruženja trebamo uzeti u obzir i analizu zainteresovanih strana ili stejkholdera (eng. stakeholder). Termin stejkholder se odnosi na svaku osobu, grupu ili instituciju koja ima određene relacije sa organizacijom, i koja realizacijom strategije može nešto dobiti ili izgubiti, samim time što je strategijski dokument obimniji, to je i lista stejkholdera duža. Postoje različiti pristupi analizi stejkholdera.

\footnotetext{
${ }^{37}$ Pearce, J., Robinson, R., Strategic Management: Formulation, Implementation and Control, McGraw-Hill, New York, 1991.

38 Jovanović, P., Isto, str. 269.

${ }^{39}$ Akronim engleskih reči: Strenghts - snaga, Weakness - slabosti, Opportunities - šanse, Threats - opasnosti.
} 
Strategijski menadžment je proces koji je u potpunosti okrenut budućnosti, sledstveno tome neophodno je predvideti buduća stanja i događaje, odnosno predviđati budućnost kako bi se mogli definisati ciljevi koje želimo postići i definisati strategije čijom realizacijom bi se stiglo do definisanih ciljeva. ,,Da bi se krenulo sa definisanjem strateških ciljeva i određivanjem strategije preduzeća čijom realizacijom se dostižu zacrtani ciljevi u budućnosti, neophodno je da se, pored sadašnjih potencijala preduzeća i stanja okoline, zna nešto više o budućnosti, o budućim događajima koji mogu da nastanu, o promenama koje se očekuju u budućnosti, i o budućim parametrima koji će se ostvariti i koji će opisivati buduća stanja i ponašanja. “40

Prema jednom delu autora faza definisanja misije $i$ strateških ciljeva uzima se kao prva faza strategijskog menadžmenta, odnosno kao ishodište za definisanje strategije. Međutim, pre definisanja misije, neophodno je imati viziju, odnosno verovanje i filozofiju na koju se organizacija može osloniti pri realizaciji upravljačkih funkcija, a naročito kada želi da definiše svoju misiju i ciljeve. Vizija je iskaz o željenom budućem stanju organizacije, odnosno opis budućeg stanja koje organizacija želi da dostigne, i treba da odgovori na pitanje ,„šta mi želimo da postanemo?“. Ovde treba naglasiti da vizija ne predstavlja željeni krajnji cilj, već ona predstavlja ,,putokaz" za izbor boljih mogućnosti. Vizija treba da bude: (a) jasna, (b) pozitivna, (v) ostvariva, (g) koncizna, (d) poželjna, (đ) inspirativna i (e) fokusirana.

Misija je iskaz o tome zbog čega postojimo (kao organizacija, sistem, društvo ...); misija stoga predstavlja odgovor na „putokaz“ koji pruža vizija, i treba da bude: (1) usklađena sa okruženjem; (2) realna, odnosno da odgovara resursima i sposobnostima kojima organizacija raspolaže; (3) inspirativna; (4) jednostavna, odnosno da se može lako operacionalizovati na ciljeve i zadatke i (5) jedinstvena. Ovde su date misije neke od najpoznatijih svetskih kompanija: Walt Disney Company: „Da činimo ljude srećnim.“; WalMart: ,,Da pružimo običnom narodu da kupe iste stvari kao bogati ljudi.“; i Merck: ,,Da sačuvamo i unapredimo ljudski život.“. Misija treba da odgovor na pitanje: ,„Šta je naš posao?".

Strateški ciljevi predstavljaju stanje, odnosno nivo performansi kojima organizacija teži u ostvarenju svoje misije. Definisanjem strateških ciljeva obezbeđuju se kriterijumi za izbor ostalih planskih odluka, ali i sredstvo kojima se vrši kontrola njihovog ostvarenja. Strateški ciljevi organizacije su zapravo njen svojevrstan kontrolni aparat kojim se dokazuje nivo shvatanja misije, ali i zadataka koji iz misije proističu. U literaturi se za definisanje strateških ciljeva često upotrebljava SMART pravilo ${ }^{41}$, odnosno pravilno formulisani ciljevi trebaju da budu: (1) merljivi, (2) uokvireni vremenski, (3) dostižni, (4) relevantni i (5) određeni - gledano kao akronim MUDRO pravilo.

Strateški ciljevi mogu biti definisani na sledeći način: (1) dugoročni ciljevi se izvode iz postojećih strateških dokumenata u organizaciji - elaborati, studije i slično; (2) organizacija treba da definiše svoje ciljeve čijim ostvarenjem doprinosi realizaciji opštih ciljeva i (3) ostvarenje strateških ciljeva je projektovano na period od 5 do 10 godina. ${ }^{42}$

\footnotetext{
40 Jovanović, P., Isto, str. 270.

${ }^{41}$ Akronim engleskih reči: Specific - određen, Measurable - merljiv, Archievable - dostižan, Relevant relevantan, Time-framed - uokviren vremenski.

${ }^{42}$ Petrović, D., i drugi, Isto, str. 452.
} 
Formulisanje i izbor strategije je proces čiji je glavni cilj stvaranje strategije koja će obezbediti budućnost organizaciji. Preko ovog procesa možemo sagledati kako je organizacija ocenila šanse i opasnosti, razumela strategijsku situaciju, ali i načine i metode delovanja u datom okruženju. Ovo je proces u kojem se involviraju analiza, identifikovanje, vrednovanje i izbor najcelishodnije strategijske opcije za predviđene okolnosti, uključujući i izvodljivost njihove implementacije. Međutim, tokom realizacije ovih aktivnosti trebamo voditi računa i o raspoloživim resursima organizacije.

Ovde ćemo prezentovati jedan od najčešće korišćenih metodoloških rešenja za proces formulisanja i izbora strategije. Proces se sastoji iz tri osnovna elementa: (1) strateška namera, (2) strateška procena i (3) strateške opcije. Strateška namera je esencija samog procesa, jer ona daje odgovor ,gde želimo da budemo?“. Dakle, definisana je okviru vizije i misije organizacije, ali vizija sama po sebi nije dovoljna, pa iz tog razloga strateška namera treba da kombinuje viziju sa voljom i resursima koji će pomoći da ona postane realnost. ${ }^{43}$

Strateška procena daje odgovor na pitanje ,,gde smo mi sada?", odnosno treba da proceni rezultate analiza eksternog okruženja i sopstvenih sposobnosti. Konačni rezultat je sveobuhvatna analiza o eksternom okruženju i odluka o potencijalnim izborima donetim u svetlu strateške namere koja se treba postati jasnija na kraju samog procesa. Strateško odlučivanje je najvažniji deo ovog procesa i treba da da odgovor na pitanje ,,koju ćemo opciju izabrati da bismo došli u poziciju koju želimo?" Proces odlučivanje se u načelu deli u četiri faze: (1) identifikovanje opcija, (2) rangiranje opcija po određenom kriterijumu, (3) izbor najbolje opcije i (4) preduzimanje akcije. ${ }^{44}$ lako analiza ima važnu ulogu u donošenju strateške odluke, iskustva iz prakse nam govore, da su ipak značajniji sposobnost procene i odlučivanja. Strateška odluka zahteva mudrost (stičemo je iskustvom) i analitičke sposobnosti.

Nakon definisanja strategije, sledi takođe značajan i složen zadatak, a to je primena ili implementacija, odnosno sprovođenje strategije. Strategija može biti definisana na najbolji mogući način, ali upropašćena neodgovarajućim načinom primene i/ili slabom primenom i izvođenjem primene strategije. Zbog toga se primeni strategije treba posvetiti posebna pažnja, dobro pripremiti i organizovati kako bi se efikasno realizovala. ${ }^{45}$ Strategijom se zapravo daje planski okvir za preduzimanjem određenih akcija kojima se pokreću resursi u datom vremenskom roku, jer faktički rezultati planiranja su akcije, odnosno programi i projekti.

Primena strategije ima dva aspekta: (1) formalan i (2) neformalan. Formalan se odnosi na organizacionu strukturu, odnosno definisane odnose između zaposlenih, a neformalan na organizacionu kulturu, odnosno stil rukovođenja i obrasce zajedničkih vrednosti. Izgradnja organizacione strukture se u načelu, zasniva na diferenciranju, koordinaciji i integraciji. Istraživanja pokazuju da struktura uvek prati strategiju, odnosno u većini slučajeva menadžeri pokušavaju da kreiraju organizaciju u skladu sa svojim dugoročnim planovima. $^{46}$

\footnotetext{
${ }^{43}$ Macmillan, H., Tampoe, M., Strategic Management, Oxford University Press, Oxford, 2001.

${ }^{44}$ Petrović i drugi, Isto, str. 454.

45 Jovanović, P., Isto, str. 271.

${ }^{46}$ Jovanović, P., Mihić, M., Petrović, D., Social Implications of Managing Project Stakeholders in Social Implications of e-Business, Information Science Reference, Hershey, USA, 2007.
} 
„Proces strateškog menadžmenta, se ne može efikasno odvijati bez dobrog sistema kontrole primene strategije. Ako sistem kontrole ne funkcioniše kako treba, sa sigurnošću se može reći da se primena strategije, pa time i proces strateškog menadžmenta neće odvijati na zadovoljavajući način."“47

Proces kontrole primene strategije sadrži dve aktivnosti: (1) poređenje ostvarenih rezultata u skladu sa planiranim i (2) predlaganje eventualnih korektivnih akcija u cilju ispunjenja planova. Strategijska kontrola obezbeđuje povratne informacije svim fazama procesa strategijskog menadžmenta i stvara mehanizam samokontrole. ${ }^{48}$ Ovde je bitno istaći da strategijska kontrola sadrži i reviziju kao jedan zaseban podproces. Naime, cilj revizije nije da sagledava da li je nešto ostvareno u skladu sa planiranim, već da sagledava mogućnosti organizacije, odnosno da li je nešto ostvareno i planirano u skladu sa mogućnostima. U suštini, revizija nastoji da otkloni jaz između ,,sadašnjeg“ i ,,mogućeg“, pa sledstveno tome involvira temeljnu dijagnozu, prognozu, ali i predlog promena. Revizija je zapravo posledica stava da organizacija može da postigne više, i ujedno izraz određene sumnje u prihvatljivost sadašnjeg stanja.

\section{Funkcije strategijskog menadžmenta}

Strategijski menadžment, kao specijalizovana menadžment disciplina novijeg datuma oslanja se na funkcije ili podprocese klasičnog (izvornog ili bazičnog) menadžmenta, s tim da je ovde bitno naglasiti činjenicu da strategijski menadžment kao kontinuiran i iterativan proces ima uticaj na funkcije, odnosno podprocese menadžmenta, prevashodno kroz definisanje, implementiranje, kontrolu i reviziju strategije. Definisanje funkcija menadžmenta je bio dug proces, koji je rezultovao time da i danas ne postoji konsenzus ili opšte prihvaćena lista funkcija menadžmenta, među autorima. Zajedničko za sve podele jeste da su njihove razlike minorne, pa sledstveno tome u ovom radu prikazaćemo neke od osnovnih, odnosno opštih i u literaturi najzastupljenijih podela, kao i objašnjenje osnovnih funkcija menadžmenta.

Prvu podelu funkcija menadžmenta dao je Anri Fajol 1916. godine. Ova podela se u nešto izmenjenom obliku zadržala i do danas. Prema Fajolu menadžment se sastoji iz sledećih fukncija: (1) predviđanja, (2) organizovanja, (3) komandovanja, (4) koordinacije ili usklađivanja i (5) kontrole. Sličnu, ali detaljniju podelu u odnosu na Fajola, dao je Dž. L. Masi, 1987. godine, i po njemu funkcije menadžmenta su: (1) odlučivanje, (2) organizovanje, (3) kadrovanje, (4) planiranje, (5) kontrolisanje, (6) komuniciranje i (7) vođenje ili usmeravanje. Interesantnu podelu dao je Dž. A. Kol 1994. godine, on je smatrao da se menadžment sastoji iz četiri osnovna podprocesa: (1) planiranje, (2) organizovanje, (3) motivisanje i (4) kontrolisanje.

Sredinom 50-tih godina 20. veka na Kalifornija Univerzitetu u SAD, izdvojila se jedna od modifikovanih Fajolovih podela. Ova podela ima sledeće podprocese: (1) planiranje, (2) organizovanje, (3) kadrovanje, (4) rukovođenje i (5) kontrolisanje. ${ }^{50}$ Ovu podelu navodimo jer je ona najsličnija podeli koja je trenutno aktuelna u teoriji menadžmenta, a to je podela me-

\footnotetext{
${ }^{47}$ Jovanović, P., Strateški menadžment, Grafoslog, Beograd, 1999.

48 Mihić, M., Petrović, D., Obradović, V., Strategic Project Management - Tool for Reaching Business Excellence, Project Management Review, ZPM, Ljubljana, 10 (2), 2007.

${ }^{49}$ Jovanović, P., Živković, D., Jovanović, F., Isto, str. 13-16.

${ }^{50}$ Koontz, H., O'Donnell, C., Principles of Managemenet: An Analisys of Management Functions, McGraw Hill, New York, 1955.
} 
nadžmenta na sledeće podprocese: (1) planiranje, (2) organizovanje, (3) vođenje i (4) kontrola. Ovu podelu koristimo radi objašnjenja podprocesa menadžmenta. Ovde je bitno istaći da se navedeni podprocesi nalaze u kauzalnom odnosu i ne mogu se nezavisno posmatrati, odnosno uspešan proces menadžmenta podrazumeva realizaciju svih podprocesa.

Planiranje (Planning) obuhvata definisanje ciljeva organizacije, odnosno utvrđivanje strategije i razvoj planova za dostizanje ciljeva. Postavljanje ciljeva i razvoj planova pomaže organizacijama da na efikasan i efektivan način postižu željene ciljeve. Planiranje može biti: formalno i neformalno. Formalnim planiranjem definišu se opšti i specifični ciljevi na duži i kraći vremenski period, analiziraju se i evaluiraju načini dolaska do željenih rezultata, vrši selekcija i donosi odluka o budućim aktivnostima. Produkti formalnog planiranja su konkretni planovi, koji ujedno predstavljaju procedure, smernice i uputstva po kojima: (a) članovi organizacije obavljaju aktivnosti; (b) organizacija angažuje sopstvene resurse i obezbeđuje dodatna sredstva i (v) vrši se proces kontrole i eventualne revizije.

Neformalno planiranje je uopšteno, bez detaljne razrade i doslednosti, retko se koriste pisani dokumenti i ovakav način planiranja se najčešće koristi u malim organizacijama gde je menadžer i ujedno vlasnik kompanije. Proces planiranja je od višestruke koristi organizacijama. Pre svega planiranje omogućava da se definiše pravac u kome organizacija želi da se kreće u budućem vremenskom periodu. Ako se jasno definiše pravac, onda se može operacionalizovati pravac i način delovanja organizacionih celina (jedinica) i zaposlenih.

Planovi su dokumenta kojima se definišu načini za ostvarivanje ciljeva. U okviru planova se utvrđuju aktivnosti koje treba realizovati, postupak realizacije, potrebni resursi i svi drugi neophodni elementi i koraci koje treba sprovesti da bi se ciljevi ostvarili. Planovi u organizaciji se dele u odnosu na sledeće kriterijume: (1) obuhvat planiranja, (2) vremenski period, (3) detaljnost planiranja i (4) učestalost korišćenja. Na slici 5 je prikazana veza između kriterijuma za definisanje vrste planova. Sa slike možemo videti da su strateški planovi dugoročni (srednjoročni), direkcioni i jednokratni, a operativni planovi kratkoročni, specifični i uglavnom trajni. ${ }^{51}$

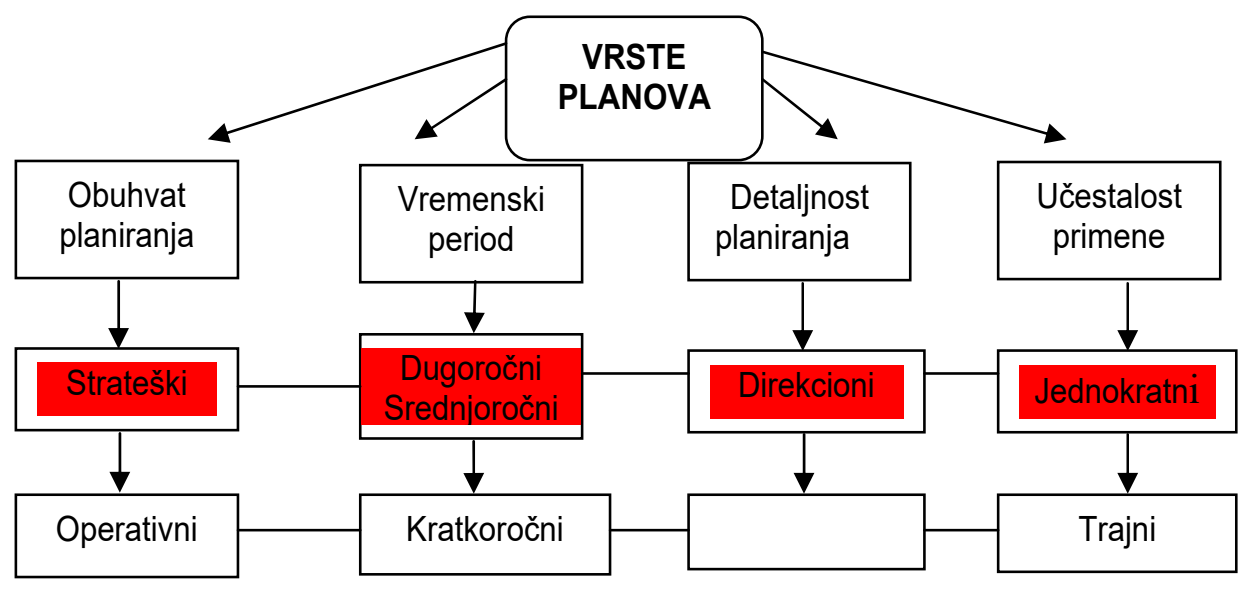

Slika 5 - Vrste planova

${ }^{51}$ Robinson, P. S., Coulter, M., Management, Data status, Belgrade, 2005. 
Organizovanje (Organizing) omogućava da se problemi u vezi realizacije aktivnosti koje su predviđene planovima svedu na minimum, i to: (a) nekoordinisan rad, (b) dupliranje poslova, (v) nejasne odgovornosti, (g) neiskorišćavanje raspoloživih resursa, (d) pogrešno obavljanje zadataka i slično. Najveći doprinos razvoju teorije organizovanja dao je nemački sociolog, Maks Veber, početkom 20. veka. Veber definiše tip organizacije, za koji je smatrao da je podjednako zastupljen u istoriji, u sistemima izvršne vlasti, ali i u preduzećima koja predstavljaju ,temelj kapitalizma“, i ovaj tip organizacije naziva birokratija. Osnovni procesi, a ujedno i karakteristike birokratije su: (1) jasna hijerarhija i podela rada, (2) detaljni postupci i propisi za izvršavanje rada i (3) izbor menadžera prema kriterijumu znanja i stručnosti. Birokratija se, sa manjim varijacijama zadržala i do danas, s tim da se danas pod organizovanjem, u načelu podrazumevaju sledeći procesi: (1) stvaranje organizacione strukture, (2) delegiranje, (3) definisanje ovlašćenja i odgovornosti i (4) menadžment ljudskih resursa.

U cilju formiranja respektabilne organizacije, trebaju se poznavati i poštovati određeni principi organizovanja. Prve principe organizovanja razradio je još Anri Fajol, 1916. godine i oni do danas nisu imali većih promena. Fajol definiše sveukupno 17 principa, među kojima su najvažniji: (1) jedinstvo komandovanja, (2) jedinstvo ciljeva, (3) raspon komandovanja, (4) hijerarhija, (5) centralizacija i (6) autoritet. Danas u teoriji menadžmenta, pored nabrojanih principa posebno se proučavaju još i sledeći principi organizovanja: (1) specijalizacija, (2) kooperacija, (3) standardizacija, (4) integracija, (5) centralizacija i (6) decentralizacija.

Vođenje (Directing) je proces usmeravanja i koordiniranja aktivnosti i ponašanja članova organizacije kako bi se na najbolji mogući način ostvarili predviđeni ciljevi. Vođenje obuhvata uspostavljanje linije komunikacije, motivaciju zaposlenih, upravljanje konfliktima i problemima, kao niz drugih aktivnosti kako bi zaposleni što efikasnije i efektivnije sproveli predviđene zadatke.

Vođenje u osnovi predstavlja složen proces dvosmerne komunikacije između poslodavca i zaposlenog, odnosno timski rad koji od menadžera zahteva prevashodno sposobnost za rad u okviru tima. ${ }^{53} \mathrm{U}$ svakom timu treba postojati hijerarhija, odnosno menadžer kao rukovodilac tima i kadrovi kao potčinjeni. Vođenje tima zahteva zajednički rad i poseban vid povezanosti menadžera i kadrova kojima on rukovodi, odnosno sinergiju. Ovde treba napraviti distinkciju između pojmova liderstva (lidership) i vođenja. Liderstvo se isključivo vezuje za lidera i njegovu sposobnost usmeravanja i vođenja ljudi, odnosno organizacije u celini, dok je vođenje uži pojam jer predstavlja usmeravanje i koordinaciju zaposlenih prilikom obavljanja određene vrste posla. U teoriji menadžmenta postoje dva pristupa u definisanju i razmatranju liderstva: (1) liderstvo kao proces i (2) liderstvo kao skup osobina, ali to je zapravo koncept koji permanentno evoluira. Na posletku vođenje obavlja svaki menadžer, a liderstvo može obavljati samo lider.

Kontrola (Controling) je vrsta postupka, koji involivira više aktivnosti, i to: (1) praćenje realizacije, (2) analize i ocene izvršenja, (3) komparaciju učinka sa postavljenim ciljevima i planiranim vrednostima i (4) sprovođenje korektivnih akcija u cilju obezbeđenja dostizanja

\footnotetext{
${ }^{52}$ Petrović, D., i drugi, Isto, str. 29.

${ }^{53}$ Tim je reč nastala od eng. Team koja predstavlja akronim Together - zajedno, Everyone - svi, Achieve dostižemo, More - više, odnosno svi zajedno možemo dostići ili postići više.
} 
ciljeva organizacije. Navedene aktivnosti se sprovode nezavisno od nivoa organizacije, odnosno strateška kontrola je namenjena praćenju i usklađivanju cele organizacije eskternom okruženju i dostizanju dugoročnih ciljeva, taktička kontrola prati i reguliše sprovođenje usvojenih strategija na funkcionalnom nivou, a operativna kontrola ima zadatak da prati i po potrebi koriguje sprovođenje aktivnosti i upotrebu resursa tokom realizacije zadataka.

Svi kontrolni sistemi se zasnivaju na zajedničkim karakteristikama koje čine osnovu za stvaranje i primenu odgovarajućih kontrolnih instrumenata. Ove zajedničke karakteristike određeni autori nazivaju i osnovnim parametrima koje treba uzeti u obzir kod definisanja budućih ili unapređenja postojećih sistema kontrole, a čine ih: (1) tačnost, (2) pravovremenost, (3) ekonomičnost, (4) fleksibilnost, (5) stepen kontrole, (6) strateška postavljenost, (7) organizaciona prikladnost, (8) višestruka provera i (9) korektivne akcije.

Kontrolu trebamo shvatiti kao svojevrstan regulator menadžmenta, kao procesa. Bez kontrole nije moguće ostvariti planirane ciljeve i rezultate, odnosno nije moguća realizacija menadžmenta, jer kontrola treba da otkloni odstupanja od planiranih ciljeva, odnosno primenom korektivnih akcija nastojimo da smanjimo jaz između planiranog i ostvarenog. Iz navedenih razloga rezultati kontrole, kao poslednjeg podprocesa, se implementiraju u planiranje kao sledeći podproces i time se omogućava da se tokom planiranja određeni ciljevi i zadaci koriguju, odnosno da se čitav proces menadžmenta učini efikasnijim.

\section{Specifičnosti primene strategijskog menadžmenta u vojnoorganizacionim sistemima}

Vojnoorganizacioni sistemi u bilo kojoj državi ostvaruju svoje mesto i ulogu u kompleksnim političkim, ekonomskim, socijalnim, bezbednosnim, tehničko-tehnološkim i drugim okolnostima. Usklađenost vojnoorganizacionih sistema sa stanjem ključnih činilaca eksternog i internog okruženja države preduslov je za uspešno funkcionisanje sistema, ali isto tako usklađenost vojnoorganizacionih sistema sa potrebama i mogućnostima države postiže se uspešnom realizacijom procesa upravljanja (menadžmenta). Sledstveno tome neophodno je razmatrati primenu strategijskog menadžmenta, kao jedne od modernih specijalizovanih menadžment disciplina u vojnoorganizacionim sistemima.

Ovo pitanje je podeljeno na dva dela koji nam daju jedinstvenu sliku specifičnosti primene strategijskog menadžmenta u vojnoorganizacionim sistemima. U prvom delu dato je pojmovno određenje sintagme vojnoorganizacioni sistemi, dok su u drugom delu prikazane primene sadržaja/modela strategijskog menadžmenta u vojnoj organizaciji, tj. u sistemu odbrane Republike Srbije, odnosno Vojsci Srbije kao osnovi sistema odbrane.

\section{Pojam vojnoorganizacionih sistema}

Sintagma vojnoorganizacioni sistemi se sastoji od dva simbola, pri čemu ,,vojnoorganizacioni“ ima konotativnu, a ,,sistem" denotativnu ulogu u označavanju. Ova sintagma je višeslojna, jer prvo trebamo napraviti distinkciju među pojmovima organizacija i sistem, a zatim uzeti obzir i da nam prefiks ,vojno“ daje smernicu o kojoj vrsti organizacije se radi, odnosno kojoj sferi ljudske delatnosti ili dimenziji društva organizacija/sistem pripada. 
Sa semantičkog stanovišta reč organizacija potiče od reči organon (grč. opyavov) koja je označavala muzički instrument, alat, napravu, ali i stvaranje organizacije, pa su shodno tome Aristotelovi učenici njegovo učenje nazvali organonom, odnosno instrumentom za spoznavanje, za realizaciju cilja, odnosno puta ka cilju. Kasnije nastaje proces širenja značenja ovog termina na drugim jezičkim područjima. Na primer u engleskom jeziku koristi se termin organisation koji označava koordiniranje u sistemsku celinu. U nemačkom jeziku koristi se termin organisieren koji označava strukturu i organizovanje. Termin organiser označava snabdeti organima potrebnim za život, oživiti; ustrojiti, ustrojavati, stvoriti po izvesnom planu i koristi se u francuskom jeziku.

Organizaciju, kao i menadžment, autori definišu na različite načine. U Leksikonu stranih reči i izraza nalazimo termin organizacije (lat. organisatio) koji se definiše kao spajanje pojedinih delova (organa) u celinu, ali tako da ta celina bude sposobna za život, organizovanje/ustrojstvo, uređenje; sastav, sklop; društvo, udruženje, ustanova. ${ }^{54}$ Definicija koja se smatra najkompletnijom za određenje pojma organizacije glasi: „,organizacije predstavljaju: (1) socijalne, (2) ciljevima usmerene entitete, (3) koji su sastavljeni od pažljivo strukturiranih i koordiniranih sistema aktivnosti i (4) povezani su sa eksternim okruženjem."

Očigledno je organizacija višeznačni termin, čija upotreba bez poznavanja sadržaja pojmova na koji se odnosi može dovesti do zabluda i nesporazuma. Organizacija je: (1) realni objekat - sistem socijalnih elemenata i relacija između njih, odnosno entitet; (2) skup aktivnosti koje su preduzete sa ciljem da se uspostave takve funkcionalne relacije između elemenata objekta koji će omogućiti realno ostvarivanje svrhe njegovog postojanja, odnosno delatnost; (3) rezultat usklađivanja elemenata unutar nekog objekta koji odražava njegovu strukturu i dinamičke osobine - atribut i (4) skup pravila, zakonitosti i metoda čija upotreba omogućuje skladno oblikovanje i efikasno funkcionisanje objekata - naučna disciplina. ${ }^{56}$

Savremeno doba je zasnovano na funkcionisanju organizacija, jer svaka organizacija ima svoju organizaciju koja je nastala organizovanjem zasnovanim na dostignućima moderne organizacije. Postoji više kriterijuma za podelu organizacija, kao na primer: po veličini (velike ili male), tipu (profitne ili neprofitne, proizvodne ili uslužne i druge) i prema delatnosti koje obavljaju (školstvo, zdravstvo, odbrana, bezbednost, privreda, politika i slično).

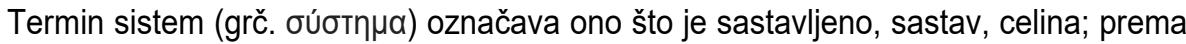
izvesnom gledištu uređena i od raznovrsnih stvari ili saznanja sastavljena celina, skup uređenih delova. $^{57} \mathrm{U}$ opštem smislu, svaki sistem predstavlja skup objekata (delova, komponenti) sa relacijama između njih i njihovih atributa (osobina, svojstava), pri čemu relacije povezuju sistem u celinu. ${ }^{58}$

„Sistem se može definisati preko sledećih svojstava: (1) sistem je složena celina uzajamno povezanih elemenata; (2) sistem obrazuje posebnu celinu sa okolinom; (3) obično je ispitivani sistem deo sistema višeg reda i može se posmatrati kao podsistem ili eleme-

\footnotetext{
${ }^{54}$ Vujaklija, M., Isto, str. 639.

${ }^{55}$ Daft, R., L., Organization Theory and Design, Thomson Learning, 2004

${ }^{56}$ Jaško, O., Čudanov, M., Jevtić, M., Krivokapić, J., Osnovi organizacije i menadžmenta, Fakultet organizacionih nauka, Beograd, 2014, str. 4.

${ }^{57}$ Vujaklija, M., Isto, str. 849.

${ }^{58}$ Vojni leksikon, VIZ, Beograd, 1981, str. 556.
} 
nat šireg sistema; (4) elementi proučavanog sistema sa svoje strane se obično javljaju kao sistemi nižeg reda. Pri tome treba obratiti pažnju na hijerarhijski karakter sistema koja je usko vezana za njegovu celovitost." ${ }^{\text {"59 }}$

Sistem je ,,strukturalno i funkcionalno jedinstvo jednovrsnih i raznovrsnih elemenata ili posebnih činilaca koji po svojim određenim svojstvima, to jest po kvalitetima, relacijama, vezama i međusobnim uticajima, čine to jedinstvo."60

„,Organizacije koje egzistiraju radi realizacije specifičnih ciljeva na području vojne delatnosti nazivaju se vojnim organizacijama. Dakle, vojna organizacija, odnosno vojnoorganizacioni sistem je svrsishodno povezan i usklađen društveni sistem čija je uloga realizacija specifičnih ciljeva na području vojne delatnosti“ ${ }^{61}$

\section{Primena strategijskog menadžmenta u vojnoorganizacionim sistemima}

Kada govorimo o vojnim organizacijama, odnosno sistemima moramo istaći njihove distinkcije u odnosu na druge organizacije, jer upravo one impliciraju model strategijskog menadžmenta koji se primenjuje u vojnim organizacijama. Distinkcije vojnorganizacionih sistema u odnosu na organizacije/sisteme iz drugih sfera ljudske delatnosti, ogledaju se u sledećem: (1) cilj postojanja vojne organizacije nije ostvarenje profita, već zadovoljenje određene potrebe društva; (2) menadžment vojne organizacije nije samostalan, odnosno ne definiše organizacione ciljeve, već se oni definisani dobijaju od strane nadležnog organa državne uprave i menadžment je zadužen samo za dostizanje zadatih ciljeva; (3) resurse za dostizanje ciljeva vojna organizacija dobija od države; (4) postojanje vojne organizacije ne zavisi od uspešnosti njenog poslovanja, već isključivo od procene državnih organa da li ima potrebe za njenim postojanjem i (5) evaluirati rezultate vojne organizacije je mnogo kompleksnije nego što je u drugim organizacijama.

lako pojam „strategija“ vuče svoje poreklo iz vojne organizacije te je odatle ušao u sva druga područja delovanja, zanimljivo je kako od sredine 20. veka, shvatanje strategije koje je oblikovano u poslovnom svetu (a koje se jako dobro uočava u sintagmi „strategijski menadžment"), sve češće ulazi u vojni, odbrambeni i bezbednosni sektor te takvo shvatanje strategije postaje dominantnije i raširenije od tradicionalnog, izvornog shvatanja. ${ }^{62}$ Dok se primera radi, opšta, velika strategija vezivala uz područje nacionalne bezbednosti i utvrđivanje ključnih interesa i ciljeva, dugoročno usmerenih, nova, poslovno oblikovana strategija u području odbrane više se veže uz kratkoročno dostižne ciljeve, prvenstveno vezane uz planiranje i izvršavanje budžetskih sredstava. S obzirom da je

\footnotetext{
${ }^{59}$ Petrović, B., Teorija sistema, Fakultet organizacionih nauka, Beograd, 1998, str. 2-10.

60 Šešić, B., Osnovi metodologije društvenih nauka, Naučna knjiga, Beograd, 1974, str. 36.

${ }^{61}$ Kovač, M., Dulanović, Ž., Stojković, D., Određivanje efikasnosti vojnorganizacionih sistema, VIZ, Beograd, 2006, str. 14.

${ }^{62}$ Na primer, američki Planning, Programming, and Budgeting System (PPBS), kao upravljačka tehnika razvijena sredinom 60-tih godina 20 . veka, te primenjena u odbrambenom sektoru sa zadatkom povezivanja operativnih zahteva i finansijskih pokazatelja, kopirana je širom sveta, selektivno, pa i pogrešno interpretirana, a u pojedinim slučajevima od upravljačkog alata postala zamena za kompletan proces na strateškom nivou.
} 
strategija u poslovnom sektoru dominantno vezana uz položaj na tržištu i mogućnost povećanja profita, ona će u svom artikulisanju naglasak stavljati na merljivost ostvarenja ciljeva (povećanje udela na tržištu, povećanje izvoza, rast produktivnosti, smanjenje troškova, rast dobiti i slično). Prevodeći alate, razvijene u okviru takvog shvatanja strategije, na područje odbrane i bezbednosti (ili uopšteno javne uprave) dolazi do redukovanja svih onih aspekata koji se ne mogu brojčano izraziti. Jedan od izlaza iz takve situacije predstavlja prilagođavanje ciljeva na način da ne budu isključivo vezani uz finansijski ili materijalni aspekt, ali da ipak budu merljivi. ${ }^{63}$

$U$ prethodnom delu rada govorili smo o specifičnosti značenja termina menadžment i koliko je zapravo teško naći adekvatan termin u našem jeziku za potpuno terminološko određenje i suštinsko shvatanje ovog termina. U sistemu odbrane Republike Srbije delatnosti iz domena menadžmenta su striktno definisane, odnosno razdvojene hijerarhijski po nivoima organizacije, a samim time i po ljudstvu i resursima. Naime, postoje tri delatnosti ili načina usmeravanja, koje možemo podvesti pod sferu menadžmenta, i to su: (1) upravljanje, (2) rukovođenje i (3) komandovanje. Zajedničko za sve tri vrste usmeravanja jeste odlučivanje, ali razlike među njima zasnivaju se prevashodno u načinu, odnosu procesu donošenja odluke. Sveobuhvatnosti termina menadžment najviše bi odgovaralo ,upravljanje“, jer je ono ishodište za odluke koje se donose u procesima rukovođenja i komandovanja. Odnos upravljanje-rukovođenje-komandovanje trebamo tumačiti prema kriterijumu opštosti, odnosno opšte-posebno-pojedinačno.

Upravljanje obuhvata sveukupne aktivnosti koje se preduzimaju radi izvršenja određenih funkcija neophodnih za ostvarenje organizacijskih ciljeva. „Upravljanje sistemom odbrane predstavlja organizovanu delatnost usmeravanja subjekata sistema odbrane Republike Srbije u izvršavanju njihovih misija i zadataka, čime se obezbeđuje delovanje i efikasno reagovanje sistema odbrane na vojne i nevojne izazove, rizike i pretnje. ${ }^{64}$ Ovde treba naglasiti da se upravljanje sistemom odbrane ne odnosi na izvođenje operacija.

„Rukovođenje je delatnost koja karakteriše organizaciju sistema odbrane Republike Srbije. Ono što postavi upravljanje, to rukovođenje realizuje. Rukovođenje je delatnost kojom se usmeravaju subjekti sistema odbrane kao celine u izvršavanju poslova i zadataka na ostvarenju ciljeva koje postavlja upravljanje." ${ }^{65}$

Vojno rukovođenje je javno obznanjivanje komandantovih odluka, uputstava i namera sa kasnijim nadzorom i prilagođavanjem izvršenja potčinjenih. Može da se vrši direktno ili indirektno, direktivom, planom ili postupcima. ${ }^{6}$

Komandovanje je funkcija organizacije koja postoji samo u vojnim i policijskim organizacijama. Komandovanje obuhvata pravo komandanta i komandira na odlučivanje i dodelu zadataka potčinjenima, a realizuje se pomoću određenih akata komandovanja: zapovesti, direktive, instrukcije, naredbe, naređenja i slično. Komandovanjem se realizuje funkcija rukovođenja. ${ }^{67}$

\footnotetext{
${ }^{63}$ Domjančić, S., Gracin, D., Kako promišljati strategiju u području sigurnosti i obrane? Polemos, Vol. XIX, br. 37, Zagreb, 2016., str. 102-103.

${ }^{64}$ Doktrina komandovanja - privremena, Generalštab Vojske Srbije, Združena operativna komanda, Beograd, 2016, str. 7.

${ }^{65}$ Isto, str. 8.

${ }^{66}$ Staff organization and operations, FM 101-5, US Army Headquarter, Department or the Army, 1999, p. 9.

${ }^{67}$ Isto, str. 39.
} 
„Komandovanje (command) podrazumeva: autoritet koji je dodeljen pojedincu da upravlja vojnim snagama; naređenje izdato od komandanta; naređenje komandanta izrečeno radi postizanja ciljeva u konkretnoj akciji; jedinica, grupa jedinica, organizacija ili prostor pod upravom pojedinca; upotreba komande. ${ }^{68}$

„Komandovanje predstavlja delatnost sistema odbrane Republike Srbije, koja je karakteristična za Vojsku Srbije i kojom se ostvaruje ono što je definisalo rukovođenje." 69 Odnos navedenih delatnosti i nosioci po nivoima vojne organizacije prikazan je na slici 6 .

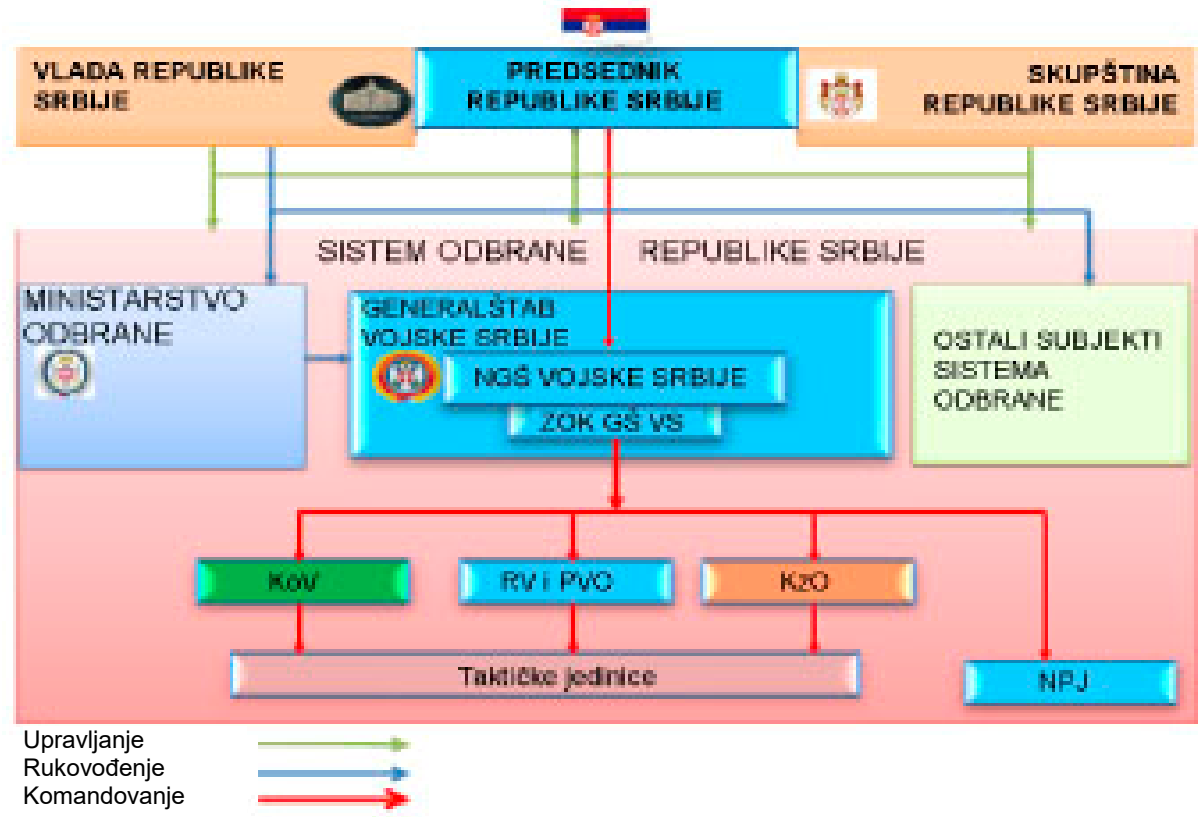

Slika 6 - Upravljanje, rukovođenje i komandovanja u sistemu odbrane Republike Srbije

Za postizanje određenog cilja komandovanja, neophodno je realizovati više međusobno povezanih delatnosti, koje su zapravo funkcije komandovanja i njima se obuhvata proces od početne do završne delatnosti. Funkcije komandovanja u Vojsci Srbije su: (1) planiranje, (2) organizovanje, (3) naređivanje, (4) koordinacija i (5) kontrola.

U vojnim organizacijama postoje tri nivoa menadžmenta: (1) strategijski, (2) operativni i (3) taktički. Strategijski nivo obuhvata vrh organizacione hijerarhije i ostvaruje integraciju kompletnog menadžmenta i odgovoran je za funkcionisanje celokupne organizacije. U nadležnosti strategijskog nivoa su: (1) utvrđivanje misije i osnovnih ciljeva organizacije, (2) izbor strategija za realizaciju tih ciljeva, (3) komunikacija sa okruženjem, (4) donošenje odgovarajućih

\footnotetext{
${ }^{68}$ NATO glossary of terms and definitions, NATO Standardization Agency, 2003, p. 2-c-8

${ }^{69}$ Doktrina komandovanja - privremena, Generalštab Vojske Srbije, Združena operativna komanda, Beograd, 2016, str. 8.
} 
strategijskih odluka i sl. ${ }^{70}$ Specifičnost vojnih organizacija se ogleda u tome da strategijski nivo često nema ovlašćenja da samostalno određuje misiju i ciljeve organizacije, ali može da ostvari značajne refleksije na nadležne organe državne uprave prilikom njihovog određivanja.

Operativni nivo obuhvata središnje hijerarhijske pozicije u vojnim organizacijama, i odgovoran je za: (1) implementaciju strategije koja je utvrđena na strategijskom nivou i (2) ima suštinski uticaj na efektivnost i efikasnost organizacije. Taktički nivo je najniži nivo menadžmenta koji izvršavanjem određenih zadataka direktno implementira strategiju. Osnovna uloga rukovodilaca tog nivoa je da motivišu neposredne izvršioce, da usmeravaju i koordiniraju njihove aktivnosti, da rešavaju konflikte i slično. ${ }^{71}$

Ovde je bitno istaći da se i komandovanje, u Vojsci Srbije takođe organizuje na strategijskom, operativnom i taktičkom nivou, ali u skladu sa mirnodopskom i ratnom organizacijom Vojske Srbije, kao što je prikazano na slici 7. Međusobni odnosi komandi, jedinica i ustanova na različitom nivou organizovanja snaga određeni su organizacijsko-formacijskom strukturom Vojske Srbije i njenih celina. Sistem komandovanja u Vojsci Srbije je jedinstven, a njegovo organizovanje se prilagođava zadacima i uslovima u kojima se izvršavaju. ${ }^{72}$

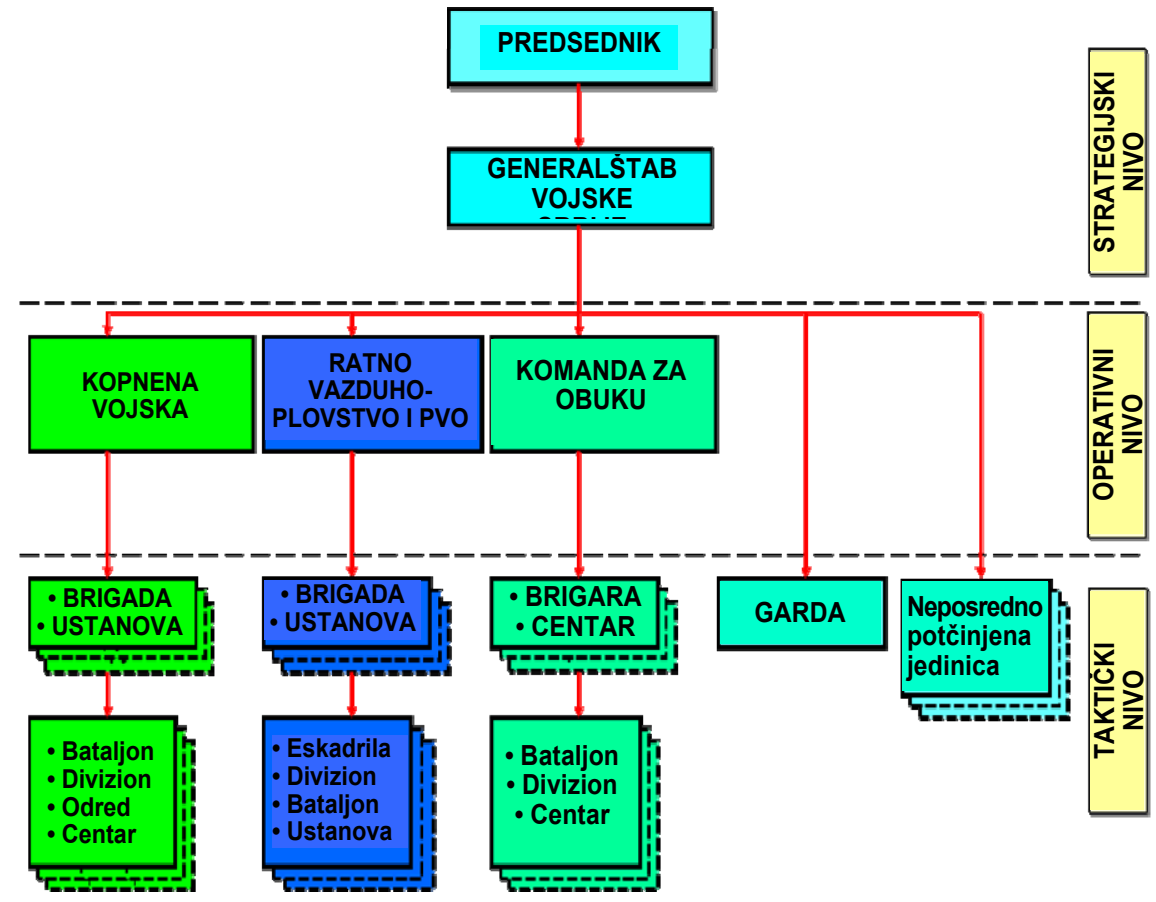

Slika 7 - Organizacija komandovanja u Vojsci Srbije

\footnotetext{
${ }^{70}$ Kovač, M., Dulanović, Ž., Stojković, D., Isto, str. 47.

${ }^{71}$ Kovač, M., Dulanović, Ž., Stojković, D., Isto, str. 48.

${ }^{72}$ Doktrina komandovanja - privremena, Generalštab Vojske Srbije, Združena operativna komanda, Beograd, 2016, str. 21.
} 
Kada govorimo o strategijskom upravljanju (menadžmentu), ali i generalno o upravljanju u vojnoorganizacionim sistemima, odnosno o uspešnosti ovog procesa, trebamo reći da je ona određena, u načelu sa dva pokazatelja uspešnosti ostvarivanja ciljeva vojne organizacije: (1) efikasnost i (2) efektivnost. Navedeni pojmovi, vrlo često se u literaturi koriste zajedno i među njima se i ne pravi jasna distinkcija, već se smatraju sinonimima.

Značajan doprinos razumevanju razlika između pojmova organizacione efikasnosti i efektivnosti dao je Piter F. Draker. Prema njegovom mišljenju efikasnost znači „raditi na pravi način" i meri se stavljanjem u odnos efekata i troškova (utrošenih resursa) da se oni ostvare. Efektivnost, pak, znači „raditi prave stvari“ i izražava se stepenom realizacije ciljeva. Ponekad se efikasnost tretira kao interni, a efektivnost kao eksterni problem organizacije. Smatra se da je efikasnost posledica dešavanja unutar same organizacije, dok je efektivnost posledica dešavanja koja utiču na odnos organizacije sa sredinom u kojoj obavlja svoju delatnost. Uspešnost upravljanja vojnim organizacijama matematički se može predstaviti kao:

\section{Uup $=f(E f e k$, Efik)}

gde je: Uup - uspešnost upravljanja; Efek - efektivnost organizacije, tj. stepen realizacije ciljeva organizacije; Efik - efikasnost organizacije, tj. odnos između ostvarenih rezultata i angažovanih resursa.

Pored efikasnosti i efektivnosti, posebno obeležje strategijskog upravljanja u vojnoorganizacionim sistemima predstavlja prožimanje sa još jednom specijalizovanom menadžment disciplinom, sa upravljanjem promenama (Mastering change). Promene su permanentna pojava, a problemi se javljaju zbog promena. Način da se problemi rešavaju jeste adaptacija na promene, a način da se poboljša rad vojne organizacije nije promena strategije, već promena internog okruženja, odnosno promena situacije. Redosled promene situacije glasi: jeste postoji problem, želim da ga rešim i treba uraditi sledeće. Zapravo suština upravljanja promenama u vojnoj organizaciji, jeste da se ,slepo“ ne držimo ranije definisanih planova, već da se rad organizacije mora adaptirati shodno nastalim promenama, odnosno u duhu misli legendarnog američkog generala i potonjeg predsednika SAD-a, Dvajta Ajzenhauera: „Planovi su ništa, planiranje je sve.“

Prema kriterijumu težini/važnosti problema, odnosno odluka koje se donose, a nezavisno od organizacionog nivoa na kome se upravljanje sprovodi, postoje dve vrste upravljanja: (1) strategijsko i (2) operativno upravljanje. Strategijsko upravljanje u vojnoorganizacionim sistemima predstavlja kontinuirani, permanentni i iterativni proces koji je usmeren na obezbeđenje ekvilibrijuma sistema i njegovog okruženja, kako eksternog, tako i internog. Rezultat ovog procesa treba da bude sposobnost vojne organizacije da pravovremeno reaguje na promene u okruženju.

Osnovne aktivnosti procesa strategijskog upravljanja vojnoorganizacionim sistemima su: (1) analiza okruženja, (2) usmeravanje organizacije (definisanje misije i ciljeva), (3) formulisanje strategije, (4) implementacija strategije i (5) kontrola sprovođenja strategije. Operativno upravljanje se, pak, može odrediti kao upravljanje transformacionim procesima kojima se strategijska opredeljenja vojne organizacije prevode u konkretne aktivnosti kojima se postižu rezultati, odnosno realizuju misija i ciljevi organizacije. Sledstveno

\footnotetext{
${ }^{73}$ Stojković, D., Organizaciono restrukturiranje vojske, VIZ, Beograd, 2008, str. 50.
} 
tome, operativno upravljanje uključuje: (1) planiranje zadataka, (2) alokaciju resursa, (3) vođenje, (4) motivisanje, (5) koordinaciju, (6) komuniciranje i (7) kontrolu. ${ }^{74}$

Ovde možemo videti da su aktivnosti strategijskog upravljanja vojnoorganizacionim sistemima identični sa modelima koje smo objasnili u drugom pitanju. Imajući u vidu da svaka delatnost u kojoj određena organizacija egzistira ostvaruje i refleksije na sam proces strategijskog menadžmenta, objasnićemo samo neke od specifičnosti za svaku navedenu aktivnost u vojnoorganizacionim sistemima.

Analiza strategijskog okruženja oduvek je bila u centru pažnje država, njenih institucija i državnika, u funkciji utvrđivanja što pouzdanije strategijske procene. Strategijska procena je rezultat analize strategijskog okruženja i skoro najbitnija faza u procesu strategijskog planiranja odbrane. ${ }^{75}$ Činioci koji određuju strategijsko okruženje stalno se menjaju, i nalaze se u kauzalnom odnosu, pa samim time zahtevaju stalnu adaptaciju u skladu sa nastalim promenama. Činioci strategijskog okruženja se mogu klasifikovati na različite načine shodno kriterijumu, međutim jedna od najčešćih klasifikacija je na: unutrašnje i spoljašnje; opšte i posebne; globalne, regionalne i nacionalne.

Za analizu eksternog okruženja razmatraju se sledeći činioci: (a) politički, (b) ekonomski, (v) materijalno-energetski, (g) socijalni, (d) naučno-tehnološki, (đ) bezbednosni i (e) drugi činioci. Cilj ove analize je utvrditi šanse i pretnje vojnoorganizacionog sistema. Ćinioci koje se razmatraju pri analizi internog okruženja su: (a) kadrovi, (b) finansije, (v) organizaciona struktura, (g) komandno-informacioni sistemi i (d) drugi činioci. Cilj ove analize je utvrđivanje snaga i slabosti vojnoorganizacionog sistema. Za analizu strategijskog okruženja i ovde se koriste tehnike: SWOT analize, SPEST(LE) analize, matrice: TOWS, IFF, EFE i IE i druge tehnike. Shodno nivou analize strategijskog okruženja, ona može biti na: (1) globalnom, (2) regionalnom i (3) nacionalnom nivou.

Usmeravanje vojnih organizacija podrazumeva određivanja vizije, odnosno njenu konkretizaciju kroz definisanje misije, ciljeva, prioriteta i zadataka. Vizija u kontekstu vojne organizacije je iskaz o željenom budućem stanju vojne organizacije, odnosno opis budućeg stanja koje vojna organizacije želi da dostigne, ali opis budućeg stanja mora se adaptirati shodno opštem društvenom ambijentu. Kao što smo već govorili misija bliže određuje viziju i treba da odgovori na pitanja: ko, kada, gde i zašto, ali ne i kako treba ostvariti definisane ciljeve kojima teži vojna organizacija.

Ciljevi predstavljaju rezultate ili efekte koje vojna organizacija želi da ostvari. Proizilaze iz vizije i konkretizuju je, a njihova uloga u vojnoj organizaciji se ogleda u sledećem: (1) treba da daju svrsishodnost aktivnostima; (2) namenjeni su za usmeravanje i koordinaciju aktivnosti; (3) predstavljaju osnovu za donošenje drugih upravljačkih odluka i (4) koriste se kao osnova za kontrolu ostvarenih rezultata.

Radi lakšeg ostvarivanja ciljeva trebaju se odrediti prioriteti među ciljevima, odnosno definisati ono što je važno i što ima prednost u odnosu na drugo, ali prilikom određivanja prioriteta neophodno je napraviti racionalan odnos. Kriterijumi za određivanje prioriteta: (1) uticaj na ostvarivanje ciljeva; (2) brzina i dugotrajnost efekata koje proizvode; (3) odnos između pretpostavljenih efekata i angažovanih resursa i (4) stepen zadovoljavanja potreba stejkholdera. Operacionalizacija ciljeva postiže se preko zadataka, koji redsta-

\footnotetext{
${ }^{74}$ Kovač, M., Dulanović, Ž., Stojković, D., Isto, str. 50.

${ }^{75}$ Kovač, M., Stojković, D., Strategijsko planiranje odbrane, VIZ, Beograd, 2009, str. 19.
} 
vlja određenu vrstu rada koju treba obaviti. Zadaci preciziraju: ko, kada, gde, šta i kako treba obaviti radi realizacije postavljenih ciljeva.

Kada govorimo o formulisanju strategije trebamo imati na umu važnost i značaj ovog dokumenta, jer on predstavlja ishodište za dalju operacionalizaciju, odnosno za razradu i usvajanje nižih dokumenata. Specifičnost strategijskog upravljanja u vojnoorganizacionim sistemima se ogleda i u tome što metodologija za formulisanje strategije involvira sve aktivnosti strategijskog upravljanja.

Za sistem odbrane Republike Srbije najviši strateški dokument u oblasti odbrane predstavlja Strategija odbrane Republike Srbije, a sam proces formulisanja, implementacije $i$ kontrole sprovođenja može se predstaviti kroz sledeće faze: (1) analiza činilaca sistema odbrane; (2) definisanje izazova, rizika i pretnji sa aspekta sistema odbrane; (3) formulisanje nacionalnih odbrambenih interesa i ciljeva; (4) definisanje organizacionih struktura; (5) definisanje načina funkcionisanja sistema odbrane; (6) izrada dokumenta strategije odbrane; (7) vrednovanje strategije odbrane; (8) izgradnja normativno-pravnih pretpostavki za primenu strategije odbrane; (9) implementacija strategije odbrane; (10) kontrola sprovođenja i delotvornosti strategije odbrane i (11) redefinisanje strategije odbrane. ${ }^{76}$

Esenciju strategijskog upravljanja vojnim organizacijama predstavlja strategijsko planiranje, koje involvira: (1) strategijsku procenu, (2) strategijsko usmerenje, (3) izradu strategijskih planova i (4) izvršenje strategijskih planova. Iz prethodno navedene metodologije vidimo da je upravo strategijska procena, odnosno usvajanje liste izazova, rizika i pretnji sistemu odbrane osnova za sve ostale podprocese upravljanja.

Prilikom formulisanja strategije treba se voditi računa da odnos između resursa i ciljeva bude u ekvilibrijumu, jer u suprotnom dolazi do raskoraka, odnosno strateškog jaza, kako je to i prikazano na slici 8. Slika ukazuje da državni organi koji odlučuju o resursima vojne organizacije trebaju biti svesni ,strateškog jaza“, odnosno šta se može dogoditi sa sistemom, ali i sa funkcionisanjem države u celini ukoliko se definisani ciljevi ne ostvare. Sledstveno tome, nadležni držani organi, odnosno donosioci političkih odluka, trebaju da preuzmu rizik i odgovornost za donošenje takvih odluka, a s druge strane vojni specijalisti trebaju donosioce odluka upozoriti na posledice (ne)ostvarenja definisanih ciljeva.

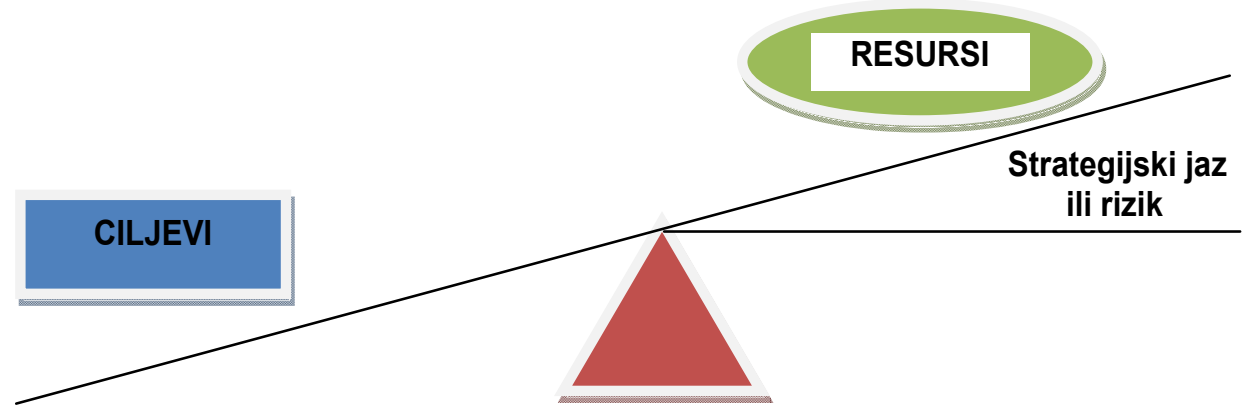

STRATEGIJE / KONCEPTI

Slika 8 - Formulisanje strategije u vojnim organizacijama

${ }^{76}$ Kovač, M., Stojković, D., Isto, str. 281-282. 
Implementacija strategije u vojnim organizacijama je poseban proces, i on podrazumeva između ostalog i: (a) razradu nižih planskih i doktrinarnih dokumenta; (b) nabavku pokretnih stvari; (v) uvođenje novih sistema (naoružanja, informacionih i slično); (g) obuka ljudstva za rad na novim sistemima; (d) promena organizacione strukture, odnosno promene unutar vojne organizacije kroz prizmu promene organizacijsko-formacijske strukture i slično. Rezultat ovog procesa su ostvarenje definisanih ciljeva, odnosno performanse sistema odbrane, koje predstavljaju način, odnosno kvalitet funkcionisanja sistema odbrane. Performanse sistema odbrane su zapravo obavljanje delatnosti iz domena odbrane na efikasan i efektivan način, prema unapred utvrđenim standardima. Upravljanje performansama, kao i upravljanje promenama, ima svoje posebne pristupe, koji zahtevaju primenu određenih mera, i to: (1) prirodnih, (2) konstruisanih i (3) indirektnih. Tok upravljanja odbrambenim performansama je cikličan i prikazan je na slici 9 , na kojoj možemo videti i koje sve aktivnosti ovaj proces involvira.

Međutim završetkom implementacije strategije, započinje jedan novi proces, a to je kontrola primene strategije odbrane i evaluacija njene delotvornosti u sistemu, odnosno performansi sistema odbrane. Nakon ovog procesa koji iziskuje određeni broj različitih analiza u zavisnosti od tipa i nivoa upravljanja sistemom, a u skladu sa novonastalim promenama u okruženju, odnosno promenama bezbednosnih trendova neophodno je izvršiti redefinisanje strategije, jer je ona dokument prilagodljivog sadržaja.

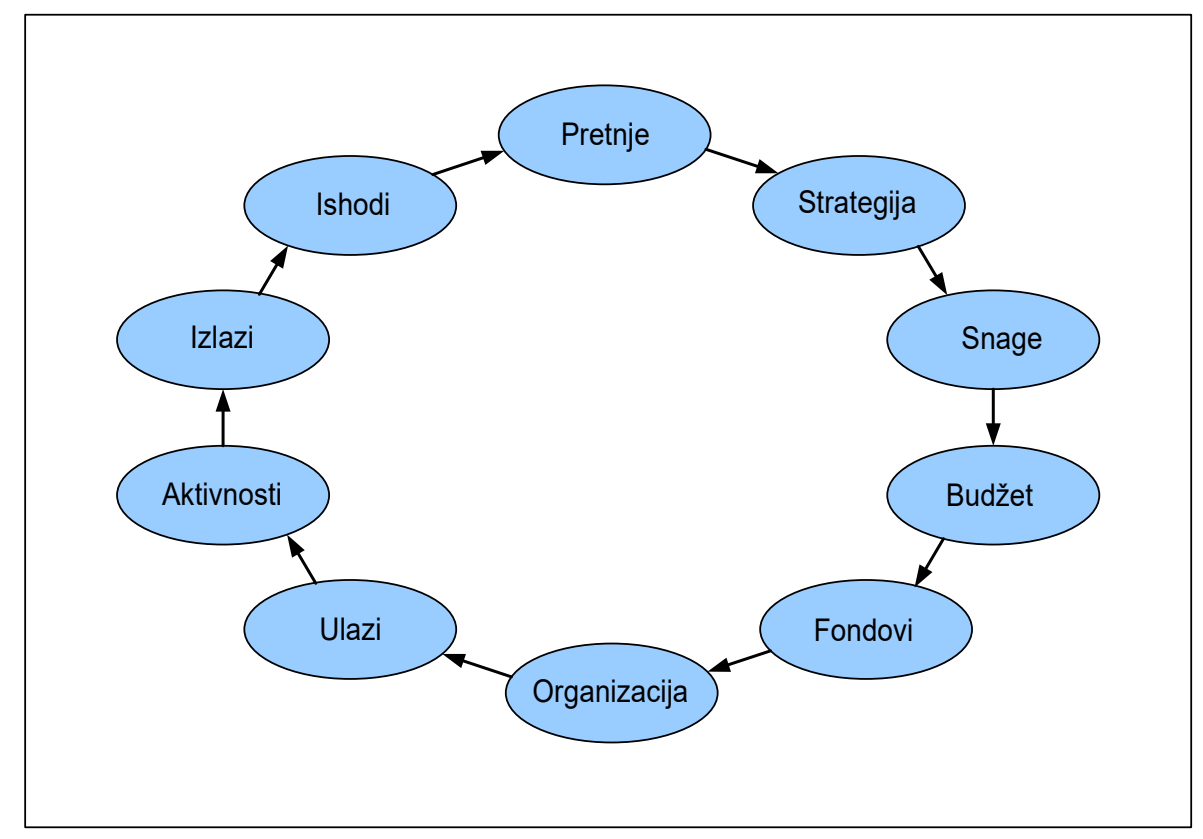

Slika 9 - Cikličan tok upravljanja odbrambenim performansama ${ }^{77}$

\footnotetext{
${ }^{77}$ Stojković, D., Isto, str. 121.
} 
Primna strategijskog upravljanja u vojnim organizacijama/sistemima je sama po sebi specifična, zapravo u ravni fenomena sa aspekta ,,klasičnih“ strategijskih menadžera, jer treba jednu neprofitnu organizaciju učiniti funkcionalnom za ostvarivanje ciljeva od opšteg društvenog značaja uz minimalan utrošak resursa, i učiniti organizaciju sposobnom da odgovori kotinualnoj promeni izazova, rizika i pretnji njenom funkcionisanju, a samim time i funkcionisanju države u celini. Sledstveno tome primena strategijskog upravljanja u vojnim organizacijama treba prevashodno počivati na shvatanju da se sve permanentno menja i da svaka promena predstavlja sredinu između dva suprotna stanja, odnosno da ovo shvatanje bude polazna osnova za sve modele strategijskog menadžmenta koje želimo primeniti.

\section{Zaključak}

Strategijski menadžment je disciplina menadžmenta koja će se nesumnjivo dalje razvijati i njegovu modifikaciju možemo očekivati shodno inovacijama u svim sferama ljudske delatnosti, ali prevashodno u nauci i ekonomiji. Ako želimo da opišemo strategijski menadžment onda treba reći da on predstavlja svojevrsno sučeljavanje organizacije sa ambijentom u kojem organizacija egzistira, i želi da ostvari ciljeve u budućnosti, a koga karakteriše kompleksnost, turbulentnost i ambivalentnost na jednoj, kao i dugoročnost posledica planskih odluka upravljačkih struktura organizacije, a naročito kada govorimo 0 angažovanju resursa, na drugoj strani.

Sledstveno tome, mnogi autori s punim pravom tvrde da je osnova strategijskog menadžmenta strategijsko planiranje ${ }^{78}$, čija osnova ležu u odlučivanju. Odlučivanje je kohezioni i katalizatorski faktor između prošlosti, sadašnjosti i budućnosti, jer prošlost zapravo simbolizuje stanje organizacije u kojoj se ona nalazi sa svim njenim prednostima i nedostacima, odnosno sposobnostima za izvršenje određenih zadataka; sadašnjost je simbol donošenja odluke u skladu sa trenutno raspoloživim resursima i stanjem organizacije; budućnost je zapravo simbol cilja, odnosno rezultata koji želimo postići u budućnosti ${ }^{79}$, ali definisanje cilja leži u odluci, odnosno u sadašnjosti.

Proces pravovremenog odlučivanja je važan da se istakne, kada govorimo o značaju primene strategijskog menadžmenta (upravljanja) u vojnoorganizacionim sistemima, jer se eksterno okruženje permanentno menja, a s obzirom na kompleksnost funkcionisanja vojnoorganizacionih sistema o kojem smo govorili u radu, dešava se da oni nisu u stanju da isprate promene i da primenom korektivnih mera i aktivnosti koriguju stanje u organizaciji/sistemu. ,Kada u tome ne uspeju ili kada se brzina promena u okruženju poveća ili se pak to dogodi, a prođe neprimetno od strane države ili njenog sistema odbrane, ulazi se u rizik takozvanog strategijskog lutanja (strategic drift). ${ }^{\text {(80 }}$ Ovde do izražaja dolazi strategijsko upravljanje, jer se jaz između napora vojne organizacije da realizuje dodatne zadatke, shodno novonastalim promenama, postaje veći srazmerno povećanju vremenske dimenzije.

\footnotetext{
${ }^{78}$ Hronološki gledano strategijski menadžment je i nastao iz strategijskog planiranja.

${ }^{79}$ Rezultat odlučivanja može biti i buduće stanje ili efekti sistema.

${ }^{80}$ Kovač, M., Stojković, D., Isto, str. 20.
} 
U procesu primene strategijskog menadžmenta u vojnoorganizacionim sistemima važno je uočiti potrebu postojanja permanentne i suštinske relacije između analize okruženja (strateške procene), odluke ili izbora opcije i same akcije, odnosno aktivnosti koja se treba sprovesti. Rezultat ovog procesa su performanse organizacije/sistema u budućnosti, ali one zapravo predstavljaju samo jedan aspekt organizacione dinamike koja treba da prati ovaj proces.

$\mathrm{U}$ ovom radu mogli smo sagledati semantičko-etiološko-istorijski tok i razvoj menadžmenta, strategijskog menadžmenta i njegovu primenu u vojnoj organizaciji. Na osnovu rezimiranja iznetih stavova možemo zaključiti sledeće: (1) nemoguće je objasniti strategijski menadžment ukoliko se ne razmatra organizacija u kojoj se on primenjuje, odnosno menadžment i organizacija su u neraskidivoj vezi; (2) strategijski menadžment u okvirima vojne organizacije je primenjiv, svrsishodan i predstavlja differentia specifica strategijskog menadžmenta koji se primenjuje u drugim delatnostima; (3) strategijski menadžment u sistemu odbrane bavi se svim aktivnostima iz domena odbrane, izuzev izvođenja operacija $^{81}$; (4) neophodan je dodatni rad vojne organizacije na polju terminološkog određenja i suštinskog shvatanja funkcija i faza ove vrste menadžmenta radi olakšanja njegove primene u praksi; (5) postoji potreba za transferom znanja, a prevashodno iskustava iz prakse, između strategijskog menadžmenta koji se primenjuje u vojnim organizacijama sa onim koji se primenjuje u drugim delatnosti ${ }^{82}$ i (6) shodno značaju funkcije odbrane zemlje u proces primene ove vrste menadžmenta neophodno je involvirati celokupne resurse države (prevashodno ljudske) i permanentno pratiti njegov dalji tok i razvoj.

\section{Literatura}

[1] Adižes, I., Upravljanje promenama, ASEE, Novi Sad, 2008.

[2] Ansoff, H., I., Corporate Strategy, Penguin Books, London, 1987.

[3] Vojni leksikon, VIZ, Beograd, 1981.

[4] Vujaklija M., Leksikon stranih reči i izraza, Prosveta, Beograd, 1980.

[5] Grant, R., Contemporary Strategy Analysis, VI Edition, Blackwell Publishing, Oxford, 2007.

[6] Gray, C. S., Why strategy is difficult, Strategic Studies a Reader, Routledge, New York, 2008.

[7] Daft, R., L., Organization Theory and Design, Thomson Learning, 2004.

[8] Damjanović, M., Menadžerska revolucija, Prosveta, Beograd, 1990.

[9] Doktrina komandovanja - privremena, Generalštab Vojske Srbije, Združena operativna komanda, Beograd, 2016.

[10] Domjančić, S., Gracin, D., Kako promišljati strategiju u području sigurnosti i obrane? Polemos, Vol. XIX, br. 37, Zagreb, 2016.

[11] Đuričin, D., Janošević, S., Menadžment i strategija, Ekonomski fakultet, Beograd, 2005.

[12] Eccles, H., Military Concepts and Philosophy. New Brunswick, N.J.: Rutgers Univ. Press, 1965.

[13] Erich, E., Definition und Gebrauch des Begriffes Strategie, Österreichische Militarische Zeitshrift, No 2, 1998.

[14] Ilić, G., Osnovi menadžmenta, Poljoprivredni fakultet, Banja Luka, 2005.

[15] Jaško, O., Čudanov, M., Jevtić, M., Krivokapić, J., Osnovi organizacije i menadžmenta, Fakultet organizacionih nauka, Beograd, 2014.

\footnotetext{
${ }^{81}$ Ukoliko govorimo o strategijskom menadžmentu u vojnoorganizacionim sistemima u užem smislu reči.

${ }^{82}$ Ovaj proces ne može i ne sme biti jednostran, već isključivo reverzibilan.
} 
[16] Jovanović, P., Menadžment - teorija i praksa, Fakultet organizacionih nauka, Beograd, 2005.

[17] Jovanović, P., Strateški menadžment, Grafoslog, Beograd, 1999.

[18] Jovanović, P., Živković, D., Jovanović, F., Menadžment i projektni menadžment, Visoka škola za projektni menadžment, Beograd, 2008.

[19] Jovanović, P., Mihić, M., Petrović, D., Social Implications of Managing Project Stakeholders in Social Implications of e-Business, Information Science Reference, Hershey, USA, 2007.

[20] Jovanović, P., Obradović, V., Petrović, D., Mihić, M., Jovanović, A., Crosscultural aspects of project management: Serbia goes to Iraq for Jordan project, International Journal of Industrial Engineering, 16(4), 2009.

[21] Johnson, G., Scholes, K., Exploring Corporate Strategy, Prentice-Hall, New Jersey, 1999.

[22] Kovač, M., Dulanović, Ž., Stojković, D., Određivanje efikasnosti vojnoorganizacionih sistema, VIZ, Beograd, 2006.

[23] Kovač, M., Stojković, D., Strategijsko planiranje odbrane, VIZ, Beograd, 2009.

[24] Koontz, H., O'Donnell, C., Principles of Managemenet: An Analisys of Management Functions, McGraw Hill, New York, 1955.

[25] Kukoleča, S., Organizaciono-poslovni leksikon, Rad, Beograd, 1986.

[26] Larusova enciklopedija, L-Š, Vuk Karadžić, Beograd, 1978.

[27] Macmillan, H., Tampoe, M., Strategic Management, Oxford University Press, Oxford, 2001.

[28] Mintzberg, H., The Rise and Fall of Strategic Planning, U: Harvard Business Review, January-February. Preuzeto sa: https://hbr.org/1994/01/the-fall-and-rise-of-strategic-planning 1994.

[29] Mihić, M., Koncept upravljanja organizacijom integrisanjem strateškog i projektnog menadžmenta, doktorska disertacija, Fakultet organizacionih nauka, Beograd, 2008.

[30] Mihić, M., Petrović, D., Obradović, V., Strategic Project Management - Tool for Reaching Business Excellence, Project Management Review, ZPM, Ljubljana, 10 (2), 2007.

[31] NATO glossary of terms and definitions, NATO Standardization Agency, 2003, p. 2-c-8

[32] Niven, P. R., Balanced scorecard: Korak po korak: Maksimiziranje učinka i održavanje rezultata. Zagreb, Poslovni dnevnik, Masmedia, 2007.

[33] Opšta enciklopedija, Jugoslovenski leksikografski zavod, Zagreb, 1982.

[34] Pearce, J., Robinson, R., Strategic Management: Formulation, Implementation and Control, McGraw-Hill, New York, 1991.

[35] Petrović, B., Teorija sistema, Fakultet organizacionih nauka, Beograd, 1998.

[36] Petrović, D., i drugi, Menadžment i organizacija, Fakultet organizacionih nauka, Beograd, 2011.

[37] Politička enciklopedija, Savremena administracija, Beograd, 1975.

[38] Robinson, P. S., Coulter, M., Management, Data status, Belgrade, 2005.

[39] Staff organization and operations, FM 101-5, US Army Headquarter, Department or the Army, 1999.

[40] Stojković, D., Organizaciono restrukturiranje vojske, VIZ, Beograd, 2008.

[41] Strachan, H., The lost mening of Strategy, Strategic Studies a Reader, Routledge, New York, 2008.

[42] Certo, S., P., Strategic Management: Concepts and Applications, McGraw-Hill, New York, 1991.

[43] Walker, G., Modern Compettive Strategy, International Edition, McGraw-Hill, New York, 2007.

[44] Yarger, R. H., Towards A Theory of Strategy: Art Lykke and the Army War College Strategy Model. Preuzeto sa: http://www.au.af.mil/au/awc/awcgate/army-usawc/stratpap.htm, 2008. 